\author{
Andrzej A. Zięba \\ (iD https://orcid.org/0000-0003-4922-6249 \\ Uniwersytet Jagielloński
}

\title{
Między Rosją a Czechosłowacją: Ruś łemkowska w polityce międzynarodowej w dobie starań o podmiotowość polityczną, 1918-1921
}

Резуме

Медже Росийом а Чехословацийом. Лемківска Русь в медженародній політыці в період старань о політычну підметовіст, 1918-1921 Подіі на Лемківскій Руси, якы мали в роках 1918-1921 підметово-політычный характер, были ефектом власных ініциятыв і діянь єй жытели, а не лем зовнішніх інспіраций і влиянь. Были свідоцтвом народового дозріваня лемківской спільноты. Єднак тверджыня, же творены товды лемківскы рады стремили або аж і покликали власну лемківску державніст з центром в селі Фльоринка, не ма основаня. Формальні на справу смотрячы, то єст з перспектывы права і медженародных одношынь, Лемковина найперше хотіла приналежати до росийской державы, а пак до Чехословациі, все рішучо одмітуючы приналежніст до одроджаючой ся Польщы і твореной од основ Украіны. Чехословация не была при тым для лемківскых політыків альтернатывом в однесіню до Росиі, але лем тактычном конечністю в ситуациі хвильовой, як думано, неможности довершыня первістной росийской опциі. Была вытвореным укладом обставин даного часу припадком. Росия явила ся як власна держава Лемків в стисло народовым сенсі, то єст така, приналежніст до якой выполнят обі важны для іх соспільства критериі - політычну і культурову. Чехословацка опция покус вымусила, 
а радше уактуальнила другій вариянт, то єст стремліня до створіня локальной державности в шыршій як лем регіон Лемковины формулі, яка лучыла бы вшыткых жыючых в Австро-Мадярах Руснаків, то значыт тіж східньогалицкых, буковиньскых і мадярскых. Така карпаторусиньска республика мала быти заступчым бытом, конечным з формальных причын, як автономічный елемент в федеральній структурі чехословацкой державы, а тіж з політычных причын, як забезпечыня для народовых аспіраций Карпатскых Русинів і гарант іх будучого зєднаня з демократычном Росийом. О кілько Росия, так царска, як і ліберальна, кєруючы ся свойом народовом доктрином, была охоча безусловні обняти своіма границями вшыткых австромадярскых Русинів, з найдале на захід высуненыма Лемками включні, о тілько проводирі Чехословациі хотіли взяти лем тілько, кілько - як думали - будут в силі спожыткувати економічні і політычні, то єст регіоны богаты в міста або земны засобы. Бідну і нерозвинену Лемковину узнавали лем за выгідный в грі о границі з Польщом предмет.

Ключовы слова: Лемковина 1918-1921, галицкы Русины, карпаторусиньска дияспора в Америці, польско-росийскы реляциі, польско-чехословацкы реляциі, лемківско-украіньскы реляциі, мирна конференция 1919

\section{Summary}

Between Russia and Czechoslovakia: Lemko Rus' Struggle for Political Independence in the Years 1918-1921 and International Politics

The events in Lemko Rus had, in the years 1918-1921, a subjective and political character, and were the result of Lemkos' own initiatives and activities, and not just external influences. They proved to be the national maturation of the Lemko community. However, it cannot be said that the newly created Lemko councils aimed at or constituted their own Lemko state with the headquarters in the village of Florynka. It becomes clear after analysing the chronology of Lemko political postulates in the context of events in the regional and global plane. None of the subsequent stages of the process of specifying their nationality by the Lemkos was connected with the idea of a separate Lemko statehood. Formally speaking, i.e., from the perspective of law and international relations, the Lemko region first wanted to belong to the Russian state, then to Czechoslovakia, always strongly rejecting the notion of being part of the resurgent Poland and the then-created Ukraine. Czechoslovakia was not an alternative to Russia for Lemko politicians, but only a tactical necessity against the momentary, as it was believed, impossibility to implement the original Russian option. It was a case created by a coincidence of ad-hoc circumstances. Be the Lemkos' own country in the 
national sense, that is, they met both the political and cultural criteria of belonging there, which were important to their community. The Czechoslovak option somehow forced, or rather made possible the second option striving to create a local state with a wider formula than just the Lemko region, connecting all Rusyns living in Austria-Hungary, that is also those from Eastern Galicia, Bukovina and Hungary. Such a Carpatho-Ruthenian republic was supposed to be a substitute, necessary for formal reasons, as an autonomous element in the federal structure of the Czechoslovak state, and for political reasons, as a safeguard for the national aspirations of the such a Carpatho-Rusyn and a guarantee of their future unification with democratic Russia. While Russia, both tsarist and liberal, guided by its national doctrine, was willing to unconditionally include all Austro-Hungarian $\mathrm{Ru}$ thenians in its borders, including also westernmost Lemkos, Czechoslovak leaders wanted to bite only as much as they could chew economically and politically, i.e. - include only regions rich in cities or natural deposits. The poor and non-urbanized Lemko region was treated only as a convenient item in their subversive game of borders with Poland.

Key words: Lemko region 1918-1921, Galician Rusyns, Carpathian diaspora in America, Polish-Russian relations, Polish-Czechoslovak relations, Lemko-Ukrainian relations, 1919 peace conference

Nie jest zadaniem historyka uleganie lub tworzenie zmistyfikowanych narracji historiograficznych, swoistych fan-fiction. Odwrotnie, jest on zobowiązany do opowiadania historii prawdziwej, w tym wymiarze prawdziwości, jaki można ustalić. Z tego założenia wychodzi poniższa próba krytyki przekazów pamięci społecznej oraz historiograficznych interpretacji wydarzeń politycznych na Łemkowynie w latach 1918-1921, które są nam znane pod nazwą Ruskiej Republiki Łemków. Jak każdy mit, także i ten zawiera w sobie ziarno prawdy, dotyczącej wydarzeń z marca $1920 \mathrm{r}$. Jednak fakt ten już w tamtym czasie został otoczony kokonem zmyśleń zniekształcających jego realne wymiary, co stało się nawet powodem postawienia kilku działaczy łemkowskich przed sądem w Nowym Sączu. Choć podczas rozprawy w czerwcu 1921 r. zaprzeczyli oni istnieniu państwa łemkowskiego i tworzeniu jego rządu, wręcz wyśmiali taką interpretację swych czynów, a ich zeznania tenże sąd uznał za prawdziwe i dające podstawę do wyroku uniewinniającego, procesowi mitotwórczemu to nie zaszkodziło. W tym samym czasie publicyści gazet karpackoruskich, takich 
jak lwowska „Prikarpackaja Ruś” i nowojorski „Prołom”, w korespondencji z procesu sądeckiego używali określenia „Łemkowskaja Respublika” (Horbal 1997, 172). Mit więc się umacniał, dzięki kolejnym swym wysłowieniom (Флюнт 1930; Теодоровичъ 1934, 12; Коковський 1935, 115-117; Ваврик b. d.; Пельц 1962 itd.), aż stał się treścią uczonych rozpraw, dowodzących istnienia na Łemkowynie państwowości z gatunku efemeryd, najdłużej - bo aż nieco ponad dwa lata - istniejącej w porównaniu do innych, spotykanych w tym czasie i regionie po pierwszej wojnie światowej (Осечинський, Челак 1957; Шанковський 1974, 176-180; Magocsi, 1993, 95).

Opisanie wydarzeń rzeczywistych, to jest zgodnych nie z interpretacjami obserwatorów, komentatorów czy kontynuatorów, ale z intencjami ich twórców, wymaga właściwie tylko jednego - zdystansowania się od języka mitu. Dlatego, zamiast stosować określenie „republika” lub „rząd”, używać będę terminologii zgodnej z miarodajnymi źródłami wytworzonymi przez te instytucje, które mit mianował ową republiką i rządem, czyli łemkowskie rady. Co do istoty rzeczy mit nie kłamał - ruch rad łemkowskich był zjawiskiem bez wątpienia państwotwórczym w swych celach. Wydarzenia na Rusi łemkowskiej miały w latach 1918-1921 charakter podmiotowo-polityczny, były skutkiem własnych inicjatyw, decyzji, działań, a nie tylko zewnętrznych inspiracji i oddziaływań. Dowodziły narodowego dojrzewania wspólnoty łemkowskiej, to jest powstawania narodu, bo naród - najkrócej rzecz ujmując - to połączenie bytu kulturowego danej wspólnoty z jej odczuciem własnej podmiotowości politycznej. Jednak stwierdzenie, że rady łemkowskie dążyły lub wręcz stworzyły własną łemkowską państwowość z centralą we wsi Florynka lub gdziekolwiek indziej, nie ma podstaw źródłowych i dowodzi niezrozumienia istoty dążeń politycznych Łemków w tamtym momencie historycznym, to jest po pierwszej wojnie światowej. Co zatem było tą istotą?

Odpowiedź na to pytanie trzeba rozpocząć od analizy chronologii łemkowskich postulatów w kontekście wydarzeń na szerszej arenie regionalnej i światowej, gdyż tą drogą możemy dostrzec etapy politycznego dojrzewania Łemkowyny, to jest zrozumieć rolę impulsów zewnętrznych, wobec których działacze łemkowscy się określali, dążąc do samodzielnego wyboru swej przynależności państwowej. Żaden z tych etapów nie łączył się z ideą osobnej państwowości łemkowskiej. Formalnie rzecz biorąc, to jest z perspektywy prawa i stosunków międzynarodowych, Łemkowyna najpierw chciała należeć do państwa rosyjskiego, a następnie do Czechosłowacji, zawsze zdecydowanie odrzucając przynależność do odradzającej się Polski i tworzonej od podstaw 
Ukrainy. Czechosłowacja nie była przy tym alternatywą dla Rosji, ale tylko taktyczną koniecznością wobec chwilowej, jak wierzono, niemożności zrealizowania pierwotnego postulatu. Czechosłowacja stanowiła tylko przypadek, wytworzony przez zbieg doraźnych okoliczności. Rosja jawiła się jako państwo własne w sensie narodowym, to jest takie, do którego przynależność w najwyższym stopniu spełnia oba kryteria ważne dla społeczności łemkowskiej - nie tylko kryterium polityczne, ale także kulturowe. Opcja czechosłowacka miała naturę techniczną i niejako wymusiła, czy może raczej uaktualniła potrzebę stworzenia lokalnej państwowości - karpackoruskiej, a więc o formule szerszej niż tylko region Łemkowyny. Państwowość ta miała połączyć wszystkich Rusinów mieszkających w Austro-Węgrzech, czyli oprócz Łemków w dawnej Galicji Zachodniej, także Rusinów wschodniogalicyjskich, bukowińskich i węgierskich. Taka karpackoruska republika - w tym wypadku ten termin jest zasadny - miała być bytem zastępczym, potrzebnym ze względów formalnych, jako autonomiczny element $\mathrm{w}$ federalnej strukturze państwa czechosłowackiego, oraz ze względów politycznych, jako zabezpieczenie dla narodowych aspiracji Rusinów Karpackich i gwarancja ich przyszłego zjednoczenia z Rosją demokratyczną. Kończąc formułowanie swej tezy, dodam tu jeszcze, że o ile Rosja, zarówno carska, jak i liberalna, była chętna do bezwarunkowego włączenia w swe granice wszystkich austro-węgierskich Rusinów, z zamieszkującymi tereny wysunięte najbardziej na zachód Łemkami, powodując się w tym dążeniu swoją doktryną narodową, o tyle przywódcy Czechosłowacji kierowali się wyrachowaniem, chcieli wziąć tyle, ile zdołają skonsumować ekonomicznie i politycznie. Mieli apetyt na regiony zasobne w miasta lub złoża ropy naftowej, Łemków oraz ich ubogą, niezurbanizowaną, wymagającą dotacji i inwestycji Łemkowynę potraktowali wyłącznie jako przedmiot wygodny w dywersyjnej grze z Polską.

\section{Łemkowie w polityce międzynarodowej przed rokiem 1918}

Podstawowa faktografia lat 1918-1921 na Łemkowynie jest nam dziś znana głównie dzięki pracy Bogdana Horbala (1997). Choć zatem pozostało jeszcze co nieco do ustalenia, to jednak rewelacyjnych danych nie można się spodziewać, bo polityka $\mathrm{w}$ tym regionie nawet $\mathrm{w}$ dobie międzynarodowych turbulencji miała spowolnione tempo, nie była dynamiczna, choć nie brak jej było dramatyzmu. 
O tym, że i na Łemkowynie, krainie pozostającej na marginesie wielkich wydarzeń, dojdzie do starcia interesów międzynarodowych wiedziano już przed wybuchem wielkiej wojny w 1914 r. Cała Galicja zamieszkana przez ludność ruską była już wtedy obiektem rywalizacji między Austrią a Rosją. W tej rozgrywce uczestniczyli od dziesięcioleci politycy polscy, a na początku XX w. włączyli się do niej Ukraińcy ze wschodniej Galicji. Za tym poszło zainteresowanie ze strony innych podmiotów międzynarodowej gry politycznej (Niemcy i Wielka Brytania), choć objawiające się tylko poprzez obserwację, a nie uczestnictwo. Rusini galicyjscy byli rozdarci pomiędzy dwie koncepcje polityczne. Koncepcja ukraińska była jednocześnie austrofilska, z początku wspierana przez polskich konserwatystów, w których ślady poszli też socjaliści, zaś tuż przed i w trakcie trwania wojny coraz bardziej otwarcie finansowana i sterowana $z$ Berlina. Wiele wskazuje na to, że na politykach ukraińskich zamierzały oprzeć swe rządy w Galicji te kręgi wiedeńskie, które związane były z nowym cesarzem Karolem I, rządzącym od 1916 r., i z naczelnym dowództwem armii austro-węgierskiej. Koncepcja przeciwna, uznająca kulturową jedność wszystkich dziedziców Rusi, liczyła, że w wyniku wojny dojdzie do zjednoczenia ruskich obszarów Galicji i Bukowiny oraz Rusi węgierskiej z Rosją, czyli do odbudowy a nawet rozbudowy historycznej postaci Rusi Kijowskiej, spojonej jednością religijną, czyli prawosławiem. Wsparcie zewnętrzne dla tej koncepcji ograniczało się do Moskwy oraz diaspory rusińskiej w Ameryce Północnej. Przeciw niej występował Wiedeń. Polacy znajdowali się w trudnej do rozwikłania sytuacji: politycy ukraińscy deklarowali się jako wrogowie interesów polskich w Galicji, podobnie jak Rosja. Celem działań polskich w dobie pierwszej wojny światowej musiało więc być przeciwstawienie się obu zagrożeniom - ukraińskiej „hajdamaczyźnie" i ruskiemu "moskalofilstwu”. We wszystkich tych programach i działaniach Łemkowie nie byli traktowani osobno, ale widziano w nich część Rusi galicyjskiej. Ich ziemia uważana była jednakże za specyficzną pod względem kultury i nastawienia politycznego, za obszar koncentracji tożsamości ruskiej w lokalnym - odmiennym od wschodniogalicyjskiego - wydaniu, stanowczo przeciwnej Ukraińcom, opowiadającej się za Rosją i sprzyjającej prawosławiu. Łemkowyna była bastionem rusofilów, w który Rosja zakulisowo inwestowała, i jako taka pozostawała jeszcze przed wojną pod szczególną obserwacją policji i kontrwywiadu austriackiego (Mostowicz, Rybak 1954, 56-57), a po wybuchu konfliktu światowego dotknięta została ostrymi represjami austriackimi.

Niedługo po zajęciu Lwowa przez wojska rosyjskie, 10 września 1914 r., rosyjski generał gubernator Galicji, hr. Gieorgij Bobrinski, przemawiając do 
delegacji miasta Lwowa, jednoznacznie potwierdził kierunek polityczny, jaki zamierzał realizować, wymieniając w tym kontekście Łemkowynę:

Uważam za niezbędne zapoznać Was Panowie z kierunkami obecnej mej działalności. Przede wszystkim wschodnia Galicja i Łemkowszczyzna z dawien dawna stanowiły rdzenną część jednej wielkiej Rusi. Na tych ziemiach rdzenna ludność zawsze była ruską, a zatem układ na tych ziemiach powinien się zasadzać na pierwiastkach ruskich. Będę tu wprowadzać ruski język, prawo i urządzenia państwowe. [...] Na początek ograniczę się na mianowaniu ruskich gubernatorów, ruskich naczelników powiatów i ruskiej policji. Wszelkie zaś organy miejscowego samorządu, jak: magistraty, włościańskie gminy i t. p. dopuszczę do pełnienia obowiązków, rozumie się pod warunkiem, że organy te okażą się wiernymi dla rosyjskiej władzy. [...] Wszystko wyżej wypowiedziane odnosi się wyłącznie do rdzennej ruskiej ziemi. Historyczna przeszłość zachodniej Galicji - zupełnie inna. Ludność jej - polska (Janusz 1915, 155-156).

W ten sposób został oficjalnie obwieszczony w polityce międzynarodowej zamiar włączenia Łemkowyny do państwa rosyjskiego, choć jego realizacja związana była $\mathrm{z}$ działaniami wojskowymi, które mimo początkowych sukcesów rosyjskich w Galicji, stanęły temu na przeszkodzie. Paradoksalnie, w momencie, gdy Bobrinski zapowiadał podział Galicji pomiędzy Rosję i przyszłą Polskę, w ramach którego Łemkowyna miała stać się rosyjska, osiadły na niej, w Krynicy, naczelne władze austriackiej Galicji (namiestnik Witold Korytowski i Wydział Krajowy).

Równolegle do enuncjacji i działań Bobrinskiego w Galicji, trwała w Kanadzie, wśród tamtejszych emigrantów ruskich z Galicji misja Onufrija O. Gecewa. Ten Rusin galicyjski, uważający się za Rosjanina, do wybuchu wojny profesor rosyjskiego gimnazjum w Buczaczu, podczas okupacji rosyjskiej formalnie przydzielony najprawdopodobniej do Uniwersytetu Lwowskiego (za profesora uniwersyteckiego podawał się w Kanadzie), choć deklarował prowadzenie działalności odczytowej tylko wśród prawosławnych urodzonych w Rosji, faktycznie inspirował środowisko karpackoruskie, do którego zaliczali się także emigranci z Łemkowyny (Гаттас 2016, 6; Martynowych 1991, 321). Wzmocnił wymiernie akcję polityczną, prowadzoną w Kanadzie już od początku wojny przez Rusinów galicyjskich opcji rosyjskiej: Andreja Szandro, Mychajła Ostrowskiego, Julijana Andruchowycza, Wasyla Czerniaka, Kyryła Genika oraz Wiktora P. Hładyka (Hladicka). 
Kolejny impuls nadszedł z Waszyngtonu. Długo trwało, zanim wywarł wpływ na Łemkowynie, natomiast niemal natychmiast pobudził działania karpackoruskiej diaspory w Ameryce Północnej. Tym impulsem było przemówienie programowe prezydenta Wilsona, wygłoszone w amerykańskim senacie 17 stycznia 1917 r., na około dwa miesiące przed przystąpieniem Stanów Zjednoczonych do wojny. Wilson nazwał swe wystąpienie pryncypiami polityki amerykańskiej wobec konfliktu światowego. Niektóre z tych pryncypiów podziałać musiały inspirująco na te społeczności narodowe, które nie miały dotychczas prawa głosu w batalii między mocarstwami. Zaliczały się do nich także Łemkowie. Wilson stwierdził m.in., że:

Równość narodów, na których opiera się pokój, jeśli ma trwać, musi być równością praw; wzajemne gwarancje nie mogą ani rozpoznawać, ani sugerować różnicy między narodami dużymi i małymi, między tymi, które są potężne, a tymi, które są słabe. Prawo musi opierać się na wspólnej sile, a nie na indywidualnej sile, narodów, od których zależy koncert pokojowy. [...] Żaden pokój nie może trwać, ani nie powinien trwać, jeżeli nie uznaje i nie akceptuje zasady, że rządy czerpią wszystkie swoje słuszne moce ze zgody rządzonych, i że nigdzie nie istnieje takie prawo, które by pozwalało przekazywać ludy spod jednej władzy do drugiej, jak gdyby byli własnością. Uznaję to za pewnik, jeśli mogę odważyć się na jeden przykład, że mężowie stanu wszędzie zgadzają się, że powinna istnieć zjednoczona, niezależna i autonomiczna Polska, i że odtąd nienaruszalne bezpieczeństwo życia, religii, oraz rozwoju ekonomicznego i społecznego powinno być zagwarantowane wszystkim narodom, które dotychczas żyły pod władzą rządów oddanych wierze i celowi wrogich względem ich własnych. [...] Każdy pokój, który nie uzna i nie zaakceptuje tej zasady, nieuchronnie będzie drażnić. [...] Chciałbym bardzo wierzyć, że przemawiam w imieniu milczącej masy rodzaju ludzkiego zewsząa, które jak dotąd nie miały ani miejsca ani okazji, by wypowiedzieć swe prawdziwe uczucia wywołane śmiercią i ruinami, jakie na ich oczach dotknęły najdroższe im osoby i domy. [...] Proponuję, aby narody jednomyślnie przyjęly doktrynę prezydenta Monroe jako doktrynę świata: że żaden naród nie powinien dążyć do rozszerzenia swego ustroju na jakikolwiek inny naród lub lud, ale że każdemu ludowi powinno się pozostawić swobodę w ustalaniu własnego ustroju, własnego sposobu rozwoju, bez przeszkód, bez zagrożeń, bez strachu, małym wraz z wielkimi i potężnymi (Address 1917).

Zasada samostanowienia i równych praw miała dotyczyć nie tylko narodów o długiej historii, ale „każdego nowoczesnego narodu, każdej oświeconej 
społeczności”. Wilson kończył swą mowę gorącym zapewnieniem, że głoszone przez niego w imieniu Stanów Zjednoczonych pryncypia „to zasady ludzkości i muszą zwyciężyć” (tamże). Powtarzał je potem jeszcze kilkukrotnie, ale to ta pierwsza deklaracja pobudziła nadzieję wszystkich małych społeczności narodowych i zachęciła je do formułowania własnych postulatów co do przyszłości swych ojczyzn.

W przypadku Łemków ta zachęta ożywić musiała nadzieje na zjednoczenie z Rosją. Otrzymali oni jeszcze jeden znaczący impuls: obalenie caratu i przemiany demokratyczne w Rosji wywołane rewolucją lutową (marzec 1917 r.) w Piotrogrodzie. Jednak reagować na te impulsy mogła tylko diaspora karpackoruska, bo Łemkowie galicyjscy nadal pozostawali pod rządami państwa walczącego z Rosją, które represjonowało wszelkie objawy „rusofilstwa”, zarówno wśród Rusinów, jak też Polaków. Mimo agitacji ukraińskiej prowadzonej przez kilku księży greckokatolickich i świeckich inteligentów oraz sympatii polskich kilku innych księży i inteligentów, orientacja rosyjska była na Łemkowynie w tym czasie bezalternatywna - o czym świadczą debaty toczone rok później na wiecach. Dlatego aż do jesieni 1918 r. Łemkowie pozostawali nieaktywni politycznie, co znacząco różniło ich od bliższych i dalszych sąsiadów, to jest Polaków i Ukraińców galicyjskich, którzy mimo wojny działali bardzo aktywnie w wymiarze aprobowanym przez Austrię, to jest niegodzącym w jej interesy wojenne. Łemkowie nie posiadali polityków „taktycznych i taktownych" (Zięba 2010), to jest takich, którzy potrafili poruszać się w ramach bieżących możliwości, nie optując otwarcie za maksymalistycznymi programami swych społeczności.

Uzasadnienie orientacji rosyjskiej zawierała broszura przygotowana i wydana w Kanadzie przez Hładyka, pt. Прикарпатская Русь (Галичина, Буковина и Угорская Русь) (Гладик 1917). W Kanadzie podejmowano także paramilitarne inicjatywy organizacyjne (Russkije Drużiny) oraz lobbing polityczny na scenie międzynarodowej, oczywiście w takim wymiarze, jaki był osiągalny dla niezasobnych i nieustosunkowanych politycznie emigrantów, wierzących w prawdziwość słów amerykańskiego prezydenta, że nawet głos takich ma być uwzględniony przy ustanawianiu nowego porządku międzynarodowego po skończonej wojnie.

Lobbing karpackoruski zainicjowany został podczas Pierwszego Kongresu Ruskiego w Kanadzie, który obradował kolejno w dwóch miastach: od 10 do 12 czerwca 1917 r. w Winnipegu (prowincja Manitoba) i 12 lipca w Mundare (Alberta). Jego głównymi organizatorami byli: Hładyk, jako redaktor 
czasopisma „Russkij Gołos”, oraz Adam Filipowski, prawosławny proboszcz w Montrealu (nota bene winnipegskie obrady kongresu odbyły się w sali polskiego „Sokoła”). Kongres uchwalił memorandum, napisane przez Filipowskiego i Hładyka, mimo burzliwej opozycji działaczy ukraińskich, usiłujących zablokować obrady, a w swojej prasie obrzucających wyzwiskami ich uczestników („haliccy moskalofile”, „kacapy”). W ten sposób pojawił się bodaj pierwszy program polityczny, uchwalony przez wprawdzie zaoceaniczną, ale autentyczną reprezentację ludności ruskiej Galicji, w dużej mierze Łemków (bardzo aktywny podczas obrad był również Łemko, Teodor Kochan) i przy autorskim udziale jednego z nich, to jest Hładyka. Zaoceaniczne enuncjacje politycznej woli były powszechnym wówczas zjawiskiem, gdy chodzi o Europę Środkową, region poddany władzy wieloetnicznych imperiów, tłumiących aspiracje narodów i grup etnicznych. Podobnie jak Rusini, korzystali z tej drogi także inni: Ukraińcy, Słowacy, Czesi, Polacy.

Dlatego memorandum kanadyjskie można traktować jako autentyczny i niekoniunkturalny głos Łemków. Sformułowany w nim został fundamentalny postulat polityczny Łemkowyny, sprowadzający się do objęcia jej granicami państwa rosyjskiego, jako ziemi odwiecznie rosyjskiej, choć jeszcze zagranicznej:

Имъя въ виду счастье и благоденствіе обновленной и демократической Россіи, мы Прикарпатскіе русскіе выходцы, живущіе въ предълахъ Канады, радостно привътствуемъ водвореніе въ Россіи народовластія, и, исповъдуя національное и культурное единство всего русского народа, обращаемся къ русскому народу въ Россіи, какъ ровно же къ будущей мирной конференціи, за исполненіемъ законныхъ, истороческихъ правъ для Прикарпатской Руси (Галичины, Буковины и угорской Руси). Мы требуемъ освобожденія русского Прикарпатья отъ австрійского и мадьярского угнетений, му рбшительно протестуемъ противъ притязаній Поляковъ, заявляющихъ претензіи на присоединеніе Прикарпатской Руси къ будущей Польшъ Прикарпатская Русь по закону, по справедливости и по осторіи, составляеть неотьемлимую часть одного великого русского народа и какъ русскіе мы требуемъ воссиединенія съ Россіей (Меморандумъ 1917, 19-22).

Kongres wybrał trzyosobową reprezentację dla prowadzenia lobbingu międzynarodowego na rzecz realizacji tego postulatu. Weszli w jej skład: Hładyk, Filipowski i Tymofiej Fujarczuk (ten ostatni był mieszkańcem Edmonton). 
Delegaci dostarczyli memorandum ambasadom państw Ententy. Postulaty karpackoruskie docierały też oczywiście do gabinetu premiera Kanady, stale dostarczano informacje parlamentarzystom i prasie kanadyjskiej (Вожик 1927, 151-152; Войценко 1961, 218; Zięba 1998, 169-172).

Niemal w tym samym czasie odbył się podobny kongres w Nowym Jorku (13 lipca 1917 r.), zorganizowany przez galicyjskiego rusofila Petra P. Hakalaka, który zgromadził delegatów organizacji karpackoruskich z tych samych regionów (Galicja, Bukowina, Ruś Węgierska) oraz duchownych prawosławnych. Rezolucje kongresu nowojorskiego były identyczne, jak te podjęte w Kanadzie: zjednoczenie wszystkich ziem etnicznie rosyjskich w Austro-Węgrzech z „demokratyczną Rosją". Memorandum nowojorskie dostarczono do ambasad państw sprzymierzonych w Waszyngtonie (Magocsi 1976, 351-352).

Silna opcja rosyjska Łemkowyny była nie tylko znana od dawna politykom ukraińskim, choć oficjalnie zaprzeczali jej istnieniu, ale też zwalczana przez nich na różne sposoby. Pojawienie się Łemkowyny w enuncjacjach Bobrinskiego skłoniło ich do sformułowania własnych deklaracji politycznych co do jej przyszłości. 28 stycznia 1916 r. na posiedzeniu Rady Ogólnej Ukraińskiej w Wiedniu odbyła się na ten temat dyskusja. Jej podstawą były dwa referaty eksperckie przygotowane przez geografa Stepana Rudnickiego i historyka Stepana Tomasziwskiego. W rezultacie przyjęto, że polityczne aspiracje ukraińskie obejmować mają, gdy chodzi o terytorium Galicji, obszar jurysdykcji lwowskiego sądu wyższego, z dołączeniem Łemkowyny (Левицький 1928, 304). Ta decyzja była powieleniem zasięgu ambicji terytorialnych Rosji i od tej pory stała się dogmatem polityki ukraińskiej, wielokrotnie prezentowanym na różnych forach międzynarodowych.

Opcja polska była jeszcze w drugiej połowie XIX w. kulturowym i politycznym wyborem dla elit inteligenckich, czyli głównie dla rodzin księżowskich Łemkowyny. W samej Florynce, która w 1918 r. stanie się miejscem najważniejszych deklaracji o samostanowieniu Łemków, pracowali wcześniej kapłani z rodzin silnie spolonizowanych (Czyrniańscy, Jaworscy), ludzie nie tylko kultury polskiej, ale też podzielający polskie aspiracje niepodległościowe. Ich potomkowie $\mathrm{w}$ dobie pierwszej wojny światowej byli zaangażowani w polskie działania i nie identyfikowali się z politycznymi aspiracjami Łemków, a zwłaszcza z ich rusofilstwem ${ }^{1}$. Jednak te poglądy miały charakter prywatny, a sympatie polskie

Jako przykład warto tu wspomnieć Brunona Olbrychta (1895-1951), który był synem Marii Jaworskiej, prawnukiem proboszcza, a wnukiem wikarego parafii we Florynce. W czasie pierwszej wojny światowej walczył on jako oficer w Legionach Polskich w Karpatach, na Bukowinie 
nie były propagowane. Przed wybuchem wojny nie zaistniała żadna skoordynowana polska akcja polityczna, podobna do ukraińskiej, mająca na celu pozyskanie łemkowskich włościan, poza doraźnymi agitacjami w dobie wyborów parlamentarnych oraz współpracą z wójtami gmin wiejskich. Tym niemniej, polityka polska na Łemkowynie była obecna, bo na początku XX w. mieszkało tam już wielu Polaków. Były to rodziny właścicieli ziemskich, przedsiębiorców, nauczycieli, aptekarzy, leśników, kolejarzy, urzędników różnego typu, adwokatów. Istniały też enklawy zwartego osadnictwa w Męcinie, Krynicy, Żegiestowie, Muszynie, gdzie Polacy stanowili większość ludności.

$\mathrm{Z}$ takich właśnie Polaków, urodzeniem bliskich Łemkowynie i znających tamtejsze uwarunkowania, wywodził się Jan Dąbrowski, jedyny polski obserwator przemian politycznych w Karpatach, który już wtedy dostrzegł trafnie kierunek potencjalnej ewolucji aspiracji politycznych Rusinów w Galicji zachodniej i uznał go za wysoce niebezpieczny dla polskiego stanu posiadania. Był to młody historyk, urodzony w Krośnie, związany ze środowiskiem naukowym Krakowa, w czasie wojny prowadzący kwerendy badawcze na Węgrzech, gdzie ponadto reprezentował Naczelny Komitet Narodowy z Krakowa, organ grupujący większość polskich stronnictw politycznych Galicji. Opierając się na swych studiach nad dziejami stosunków polsko-węgierskich, chciał przekonać polityków polskich, że dla przyszłej Polski ważne jest utrzymanie historycznej granicy z Węgrami, a więc zwalczanie wszelkich projektów, czy to czeskich, czy słowackich, czy też ukraińskich, które zmierzały do wyrugowania Węgier z ich północnych rubieży. Dąbrowski dostrzegł możliwość oderwania ziem podkarpackich, zamieszkiwanych przez Łemków, niekoniecznie przez Rosję, którą wszyscy o to podejrzewali od kilku dziesięcioleci, ale przez zupełnie nowe w regionie siły polityczne o niezaspokojonych ambicjach mocarstwowych - Ukraińców i Czechów. Pisał w lipcu 1917 r. na łamach „Wiadomości Polskich", ważnego czasopisma politycznego związanego z Legionami Polskimi Józefa Piłsudskiego:

Przyłączenie Rusinów węgierskich do Ukrainy dałoby silną podstawę, rzecz można: podmurowanie Rusinom rozrzuconym na Łemkowszczyźnie w Galicji

i Wołyniu. W październiku 1918 r. wstąpił do Wojska Polskiego. Gdy na Łemkowynie powstawały prorosyjskie rady, on uczestniczył w wojnie z Ukraińcami w Małopolsce Wschodniej oraz z rosyjskimi bolszewikami. Od 1937 r. był generałem Wojska Polskiego. O niepodległość Polski walczyli także jego bracia, Jan Stanisław (major) i Tadeusz (kapitan) Olbrychtowie, potem profesorowie uniwersyteccy. 
zachodniej, i osady Rusinów, sięgające po stronie węgierskiej do Popradu, pomogły by posunąć wpływy ukraińskie, a może i granice na polskim Podkarpaciu aż prawie po Sącz. [...] Oto na przestrzeni prawie stu kilometrów od Popradu po Ungvar powstałaby wspólna granica czesko-ukraińska. Rozwiązano by zagadnienie, na którym łamali sobie głowy politycy ententy przez całe trzy lata wojny, znaleziono by wreszcie połączenie Czech z resztą Słowiańszczyzny z pominięciem „niepewnej” Polski. Przez piękne podtatrzańskie doliny wyciągnąć by można było rękę z Pragi przez Halicz do Kijowa i Moskwy (cyt. za: Niebezpieczeństwo, 1920, 12).

Był to jednak głos odosobniony. Większość polskich polityków, działaczy społecznych, komentatorów politycznych, a także władze administracyjne, policyjne i wojskowe były skoncentrowane na „moskalofilstwie” Rusi łemkowskiej. Dąbrowskiemu chodziło o to, że rosyjskie ambicje terytorialne, sięgające aż po Nowy Sącz, przejęła polityka ukraińska, a z drugiej strony Czesi otwarcie już aspirowali do słowackich terytoriów północnych Węgier. Dawne obawy o sympatię Rusinów do Rosji, z powodu których konserwatywni politycy polscy kilka dziesiątków lat wcześniej zdecydowali się wesprzeć ukraińskie idee narodowe, uważał za już mniej niebezpieczne, niż te nowe zagrożenia.

\section{Dezaktualizacja opcji rosyjskiej w dobie koniunktury politycznej 1918 roku}

Rewolucja bolszewicka w Rosji w listopadzie 1917 r. oraz ogłoszenie w Kijowie w styczniu 1918 r. powstania Ukraińskiej Republiki Ludowej postawiło opcję rosyjską pod znakiem zapytania. Dlatego w kolejnych miesiącach 1918 r. pojawiały się wśród działaczy karpackoruskich w Stanach Zjednoczonych jeszcze inne pomysły - autonomii w obrębie Węgier, osobnego państwa złożonego z trzech kantonów (bukowińsko-, galicyjsko- i węgiersko-ruskiego), wreszcie opcji na Czechosłowację. Choć wśród amerykańskich Rusinów z Galicji pierwotny i mający najszersze poparcie postulat zjednoczenia z Rosją nigdy nie stracił aktualności, to jednak wśród Rusinów z Węgier na pierwsze miejsce wysunął się pomysł unii z Czechosłowacją, przyjęty pozytywnie przez czeskiego przywódcę, Tomáša Masaryka. W przeciwieństwie do opcji rosyjskiej, lepiej sytuował się w szerszym kontekście stosunków międzynarodowych (Magocsi 1976, 351-352). 
W tym czasie Łemkowyna nadal leczyła rany po tragedii, której symbolem był obóz Talerhof. Dopiero co wrócili więzieni tam aktywiści łemkowscy - księża, adwokaci, włościanie. Wciąż nie podejmowali żadnej aktywności, gdyż jedni nie byli już w stanie działać z powodu utraty sił fizycznych w czasie uwięzienia, a inni obawiali się Austrii, nie przestającej ciążyć nad Galicją i nie stroniącej od metod represyjnych dla podtrzymania ostatków swej władzy. Z punktu widzenia prawa międzynarodowego było to wciąż terytorium państwa austriackiego. Radca Stanisław Hawrot raportował austriackiemu Namiestnictwu we Lwowie pod koniec września 1918 r. z Gorlic:

W południowej części powiatu, zamieszkałej przez Rusinów, akcji politycznej nie zauważono. Za pośrednictwem duchowieństwa zorganizowały się w każdej ruskiej wsi kółka „Silskiego hospodara”, które jeszcze akcji żadnej nie rozpoczęły (cyt. za: Ruszała 2015, 253-254).

Ukraiński ogląd sytuacji był z tą opinią tylko pozornie sprzeczny. Działacze ukraińscy, będący osobami zaufania dla monarchii, nie czuli się w ten sposób skrępowani, ale oni z kolei nie posiadali większego oparcia społecznego wśród Łemków dla przedsiębranych przez siebie inicjatyw. Dostrzegali narastanie upolitycznienia Łemków, jednak były to bardziej nadzieje na przejęcie reprezentacji interesów tego regionu, niż fakty. W październiku 1918 r. ich lwowski organ prasowy „Diło” donosił z Muszyny:

Взагалі, чим близше до мира, тим більший рух і заінтересовання, а заразом и занепокоєння даєтся завважати між Лемками про їх будучу долю. Ціла Лемківщина звертаєтся до українських народних оборонців в Галичині і до Української Держави щоби взяли їх в рішучу оборону перед ворожими анексійними затіями. Всюди дається тепер відчувати брак репрезентанта Лемківщини („3 Лемківщини”, za: Archiwum Akt Nowych, Centralna Agencja Polska w Lozannie, zbiór wycinków prasowych, sygn. 104, k. 159).

Inicjatywę samych Łemków wyzwolił nieoczekiwanie cesarz Karol I, a właściwie jego manifest z 16 października 1918 r., pompatycznie zatytułowany Do moich wiernych austriackich ludów i kontrasygnowany przez premiera Austrii, barona Maximiliana Hussarka. W ślad za gazetami wiedeńskimi („Wiener Zeitung”, „Neue Freie Presse”), doniosły o nim dzienniki lwowskie i krakowskie, a więc jego treść dotarła do inteligencji łemkowskiej szybciej, łatwiej 
i powszechniej niż styczniowa deklaracja prezydenta Wilsona. Władca upadającego państwa oznajmiał, że jego celem jest „wskazanie ludom Austrii dróg, na których by mogły one nie powstrzymywane przez przeszkody i tarcia rozwijać zbawiennie swoją siłę plemienną i zużytkowywać ją skutecznie dla swej duchowej i gospodarczej pomyślności”. Wskazówki te brzmiały następująco:

Należy niezwłocznie przystąpić do przebudowy Ojczyzny na jej naturalnych a przeto najpewniejszych podwalinach. Życzenia ludów Austrii muszą być przy tym starannie z sobą pogodzone i doprowadzone do urzeczywistnienia. Postanowieniem moim jest przeprowadzić to dzieło przy swobodnym współdziałaniu moich ludów, w duchu tych zasad, na których oparli się sprzymierzeni monarchowie w swej propozycji pokojowej. Stosownie do życzenia swych ludów, Austria stać się ma państwem związkowym, w którym każdy szczep na obszarze swego osiedlenia tworzy swój własny organizm państwowy. Nie przesądza się przez to bynajmniej zjednoczenia polskich obszarów Austrii z niepodległym państwem polskim. [...] To nowe ukształtowanie, nienaruszające w niczym integralności krajów świętej Korony Węgierskiej, ma zapewnić każdemu poszczególnemu państwu narodowemu jego samoistność; będzie ono jednak skutecznie ochraniać także wspólne interesy i wszędzie tam je uwydatniać, gdzie wspólność jest potrzebą życiową poszczególnych organizmów państwowych. [...] Aż do przeprowadzenia tego przekształcenia w drodze ustawodawczej pozostają w mocy bez żadnej zmiany urządzenia, istniejące dla ochrony ogólnych interesów. Mój Rząd otrzymał polecenie bezzwłocznego przygotowania wszystkich prac do przebudowy Austrii. Do ludów na których samostanowieniu będzie się opierało nowe państwo skierowuję moje wezwanie, aby współdziałały w tym wielkim dziele przez Rady Narodowe, które składając się z posłów do Rady Państwa każdej narodowości, mają zastępować interesy ludów w stosunku wzajemnym do siebie oraz w odniesieniu do mojego rządu. W ten sposób niech Ojczyzna nasza, wzmocniona jednomyślnością składających ją narodów, wyjdzie z burzy wojennej jako związek wolnych ludów (Habsburg-Lothringen 1918, 1; Neck 1968, 64).

Niemal natychmiast na całym terytorium państwa Habsburgów zaczęły tworzyć się rady narodowe, w tym też w Galicji, na Bukowinie, Rusi Węgierskiej i Śląsku Austriackim, m.in. 13 października - polska w Zakopanem, 19 października - ukraińska we Lwowie i polska w Cieszynie, 31 października - Polska Komisja Likwidacyjna w Krakowie. Nastąpiła też seria proklamacji niepodległości: 28 października - Czechosłowacji oraz Państwa Słoweńców, 
Chorwatów i Serbów, 31 października - Węgier, 1 listopada - Zachodnio-Ukraińskiej Republiki Ludowej, 12 listopada - Republiki Niemieckiej Austrii.

Delegaci łemkowskich wsi, tworzący rady w grudniu 1918 r. (Horbal 1997, 38-70), podjęli więc inicjatywę całkowicie legalną w systemie państwowości austriackiej, bo poszli za wskazówkami cesarza Karola I, i w ślad za galicyjskimi Ukraińcami i Polakami utworzyli własną reprezentację polityczną o charakterze przejściowym. Nie weszli w jej skład, jak tego chciał cesarz, posłowie do parlamentu austriackiego, co zresztą i inne rady nie potraktowały jako warunek swego zaistnienia. Łemkowie nie posiadali w $1918 \mathrm{r}$. ani jednego parlamentarzysty z własnego terytorium, natomiast na ich grudniowych wiecach we Florynce i Sanoku pojawili się Dymitr Markow i ks. Roman Czajkowski, którzy formalnie reprezentowali w parlamencie austriackim inne okręgi wyborcze, ale swoją obecnością przydali poczynaniom łemkowskim legalizmu w myśl cesarskiego manifestu o politycznym organizowaniu się ludów. Ich udział świadczył jednocześnie o wspólnym, a nie regionalnym, froncie działań wszystkich Rusinów galicyjskich odrzucających ukraińską ideologię narodowotwórczą. W działającym we Lwowie a następnie Stanisławowie prorosyjskim Ruskim Komitecie Wykonawczym (Русский Исполнителый Комитет) zarezerwowano dwa mandaty dla przedstawicieli rad łemkowskich (Mroczka 1990, 201).

Okazało się, że polscy Łemkowie nie są tak podatni na przemiany sytuacyjne, tak samo „taktyczni”, jak część ich diaspory w Ameryce, i pryncypialnie obstają przy swym fundamentalnym przekonaniu narodowym. Rady łemkowskie tworzone pod koniec 1918 r. obwieściły dokładnie taką samą wolę, co do państwowej przynależności Łemkowyny, jak Pierwszy Kongres Ruski w Kanadzie. Nie wyrażono chęci utworzenia własnego odrębnego państwa łemkowskiego, ani przystąpienia do Czechosłowacji, Ukrainy lub Polski, choć wszystkie te scenariusze były w momencie powstawania rad nie tylko ogłoszone publicznie w Ameryce i Europie, ale po części już realizowane. Podczas wieców w łemkowskich wsiach trwano przy mocnym przekonaniu, że na podstawie zasady samostanowienia narodów, ziemie ruskie państwa austro-węgierskiego powinny być wcielone do Rosji (Меморандумъ 1918), choć akurat to jedno rozwiązanie wydawało się niemal niemożliwe do ziszczenia w tym momencie stosunków międzynarodowych.

Powoływane na wiecach rady nie były władzami osobnego państwa, na co powoływał się Jarosław Kaczmarczyk podczas obrony przed sądem w czerwcu 1921 r.: 
Pan prokurator popada w akcie oskarżenia w jawną sprzeczność. Początkowo przekonuje się, iż nasza republika zorganizowała się w 1918 roku, a rząd wybrano dopiero w 1920 roku. Znaczy się, że republika istniała dwa lata bez rządu (cyt. za: Horbal 1997, 107).

Zarówno z najbliższego kontekstu sytuacyjnego (manifest cesarski), jak też z dokumentacji wytworzonych przez rady, nie wynika, żeby wyrażały one intencję powołania osobnej republiki łemkowskiej. Były jedynie narodowymi przedstawicielstwami szczebla lokalnego (powiatowego i prowincjonalnego). Nie stanowiły więc państwa ani intencjonalnie, ani prawnie. Jednostkowe enuncjacje o istnieniu Ruskiej Republiki nie są tu miarodajne. Tak jak metryki kościelne, spisywane przez jednego z księży uczestniczących w pracach rad. Rady łemkowskie po prostu wpisywały się w aktualny w 1918 r. kontekst polityczny, który zachęcał ich - tak samo jak Polaków, Ukraińców, Słowaków, czy Czechów - do wyrażenia własnych opcji w przedmiocie przynależności państwowej. Zanim zapadły decyzje mocarstw, co do losu terytoriów państw pokonanych, wyrażanie tych opcji miało być wspólnotowe, ogłaszane w imieniu całych narodów. Potem możliwy był tylko indywidualny wybór obywatelstwa w ramach określonych zasad i odnośnie tych państw, których istnienie uznają mocarstwa. Niektóre wspólnoty narodowe korzystały z tej koniunktury, aby ogłosić swe aspiracje do posiadania lub odbudowania własnej, osobnej i suwerennej państwowości, co łączyło się z wielkim wysiłkiem organizacyjnym, militarnym i dyplomatycznym. Łemkowie w czasie tej koniunktury optowali tylko za zmianą przynależności państwowej z austriackiej na rosyjską. Najwyraźniej w ich przekonaniu taka zmiana oznaczała uzyskanie podmiotowości narodowej, o co przecież w tym wszystkim chodziło.

Czy byli w tym mniemaniu tak bardzo różni od swych sąsiadów? Słowacy też przecież wybrali dla swych aspiracji narodowych formę nie osobnego państwa, ale federacji z Czechami. Galicyjscy Polacy nie mieli żadnych wątpliwości, że powinni należeć do Polski, której stolicą była już Warszawa. Galicyjscy Ukraińcy, choć z wieloma oporami, przy wielkiej pokusie pozostania w ramach projektowanej przez cesarza Karola federacji, i właściwie tylko formalnie, ale jednak ogłosili zjednoczenie z Ukrainą kijowską. Łemkowie, jako ludzie kultury ruskiej, chcieli należeć do ruskiej republiki, czyli do Rosji. Problematyczność ich opcji polegała na tym, że pod koniec 1918 r. nie sprzyjał jej układ stosunków międzynarodowych. Na miejscu Rosji demokratycznej istniała bolszewicka, której zwycięskie mocarstwa nie uznawały. Był to więc 
wybór z jednej strony realistyczny, a z drugiej - nierealistyczny. Realistyczny, bo zgodny z szacunkiem własnych sił, za małych, aby zbudować osobne państwo, oraz z własnymi przekonaniami, żywionymi od co najmniej kilku pokoleń. Nierealistyczny, bo koniunktura na samookreślenie przypadła akurat w momencie dezaktualizacji opcji rosyjskiej. Gdyby nie zwycięstwo bolszewików, może inaczej potoczyłyby się losy Łemków.

Teza o rzekomej państwowości rad tworzonych w 1918 r. w Galicji nie dotyczy tylko Łemków. Jest pochodną niechlujności języka historiograficznego. Wskutek tego niechlujstwa niektórzy autorzy nieświadomie przejęli ujęcia mitologizujące, a inni nawet je zupełnie świadomie tworzyli. Nie zważając na to, że opisują fakty historyczne $\mathrm{z}$ obszaru prawa międzynarodowego i powinni stosować terminy zdefiniowane przez tę dziedzinę wraz ze zdrowym rozsąakiem, beztrosko nazywali państwami takie byty, które tych definicji nie spełniały. Imputowali działaczom rad 1918 r. intencje tworzenia „republik”, nawet, gdy działacze ci dobitnie manifestowali zupełnie inne zamiary. Poza „republiką” łemkowską przyjęto na przykład określać analogicznym mianem także radę utworzoną przez Polaków w Zakopanem. Jak można przeczytać w nieocenionej polskiej Wikipedii, idącej tu w ślady niefrasobliwych językowo pseudohistoryków: „Rzeczpospolita Zakopiańska [to] przejściowy twór państwowy istniejący przez 27 dni, od 13 października do 16 listopada 1918 r. na terenie miasta Zakopanego i jego okolic"2. Tymczasem dokument założycielski rady polskiej w Zakopanem stwierdzał stanowczo, że nie tworzy osobnej państwowości, ale optuje za podległością państwu polskiemu:

Jeszcze bardziej pompatyczna i mistyfikująca jest narracja Wikipedii anglojęzycznej: „The Republic of Zakopane (or Commonwealth of Zakopane; Polish: Rzeczpospolita Zakopiańska) refers to an area in Galicia centered on the city of Zakopane that created its own parliament («National Organisation») on October 13, 1918. The parliament's principal goal was to join an independent state of Poland. On October 30, the Organisation officially declared its independence from Austria-Hungary and, two days later, made itself a «National Council». This was eventually disestablished on November 16 when the Polish Liquidation Committee took control of Galicia. The Republic's only president was the Polish writer Stefan Żeromski”. Głównym autorem mitologizacji wydarzeń w Zakopanem był Medard Kozłowski, miejscowy nauczyciel i aktywista (rodem jednak z Krosna), który w 1918 r. był współorganizatorem działań niepodległościowych pod Tatrami, a w 1932 r. opublikował w „Gazecie Warszawskiej” (nr 393) wspomnienie pt. Żeromski na czele Rzeczypospolitej Zakopiańskiej. Ponieważ biografia Żeromskiego jest przedmiotem nauczania w każdej polskiej szkole, „Rzeczypospolita” Zakopiańska i „prezydentura” pisarza zostały szeroko upowszechnione w świadomości społecznej. Kolejne wysłowienia tego mitu to np. sztuka teatralna Anny Sudlitz (Teatr Polskiego Radia, 1978) i liczne wydarzenia medialne w roku obchodów 100. rocznicy odzyskania przez Polskę niepodległości. 
Wobec przyjęcia zasad pokojowych prezydenta Stanów Zjednoczonych Wilsona przez państwa rozbiorowe, uważamy się odtąd za obywateli wolnej, niepodległej i zjednoczonej Polski. Tej Polsce winniśmy wierność i posłuszeństwo, mienie i krew naszą, nie uznajemy żadnych więzów, tym najświętszym obowiązkom przeciwnych. Przejęci ważnością godziny dziejowej dla wspólnego gorliwego pełnienia obowiązków wobec państwa polskiego postanawiamy stworzyć Organizację Narodową w Zakopanem i w tym celu wybieramy jej zarząd, złożony z 32 osób, polecając mu ułożenie programu i sposobu działalności.

Ponadto działacze zakopiańscy (Stefan Żeromski i Mariusz Zaruski) już 10 października weszli w skład prezydium powiatowej Organizacji Narodowej w Nowym Targu - bynajmniej nie parlamentu, lecz lokalnej reprezentacji politycznej - podobnie jak działacze podobnych zakopiańskiej rad z Czarnego Dunajca, Ludźmierza, Cichego, Krościenka (Biblioteka Naukowa PAN i PAU, sygn. 4175, k. 36-37). Tak więc Zakopane niczym szczególnym nie wyróżniało się na całym Podhalu, chyba że przyjmie się absurdalną wykładnię, że w każdej z tych wiosek istniała osobna „republika”.

Takie same rady, jak zakopiańska i łemkowskie, tworzono w Galicji co kilkanaście kilometrów, między innymi w: Dąbrowie, Bochni, Sanoku, Krośnie, Jarosławiu, Ropczycach, Rzeszowie, Żywcu, Tarnobrzegu, Strzyżowie, Kolbuszowej, Oświęcimiu, Pilźnie itd. Choć działały spontanicznie i przez czas jakiś niezależnie, intencje ich tworzenia oddaje dobrze sformułowanie użyte przez przewodniczącego rady jarosławskiej, Krzanowskiego, który stwierdził, że jego rada pracuje: „w zastępstwie rządu narodowego" (Biblioteka Naukowa PAN i PAU, sygn. 4175, k. 14). Przy radach tworzono tzw. wydziały lub komitety zarządzające, które spełniały lokalnie kompetencje władzy wykonawczej. Zajmowały się organizacją aprowizacji i żandarmerii, bezpieczeństwem transportu kolejowego, przepływem informacji publicznej. Rady były więc zjawiskiem w całej Galicji powszechnym i w jego kontekście należy interpretować role i funkcje rad łemkowskich oraz definiować ich charakter.

Wszystkie te ciała mieściły się całkowicie w modelu znanym dobrze z czasów austriackich - rad powiatowych z wydziałami wykonawczymi, tyle że w 1918 r. ich członków obierano na wiecach ludowych, a nie w drodze wyborów powszechnych, i nie razem we wszystkich kuriach, na które byli podzieleni zgodnie ze swym statusem społecznym wyborcy za czasów Austrii, ale osobno, w pewnym sensie też w kuriach, tyle że etnicznych: polskich, żydowskich, łemkowskich. Większość rad galicyjskich miała bowiem charakter narodowy lub 
etniczny. Obok polskich tworzyły się w tych samych miastach rady żydowskie, w odróżnieniu od łemkowskich optujące za Polską. Na przykład Prowizoryczna Rada Ludowa Żydowska utworzona 8 listopada 1918 r. w Gorlicach wydała memoriał, w którym oznajmiała, że „wita entuzjastycznie zmartwychwstałe państwo polskie" (Biblioteka Naukowa PAN i PAU, sygn. 4174, k. 77-79). Żydowska Rada Narodowa powstała też w Krakowie (potem jej agendy przejął Zjednoczony Komitet Żydowski dla Ochrony Ludności Żydowskiej). Takie rady powstawały także w innych miastach i miasteczkach Galicji.

Tworzenie się rad było wręcz konieczne $z$ uwagi na zanikanie władzy austriackiej. Powołując je do życia, dbano nie tyle o manifest cesarski, ile o własne bezpieczeństwo i ład publiczny. Na porządku dziennym były napady rabunkowe zwłaszcza na miasteczka, szturmy sklepów i magazynów podejmowane przez wałęsające się grupy dezerterów lub zdemoralizowanych jednostek. Aby ludność cywilna mogła się obronić, rady organizowały straże i gwardie cywilne - polskie, żydowskie, oraz mieszane etnicznie pod polskim przywództwem. Zachęcała do tego Polska Komisja Likwidacyjna, nawet rozdawała takim grupom broń z własnych zasobów, jak to miało miejsce w przypadku Żydowskiej Straży Bezpieczeństwa w Krakowie (Biblioteka Naukowa PAN i PAU, sygn. 4254, k. 2). W innych miejscowościach uzbrajali straże i policje lokalni posiadacze ziemscy lub fabrykanci. Tak postąpili na przykład hrabiowie Potoccy w Łańcucie.

Problemy interpretacyjne występują też, gdy chodzi o definicję tworów wyższej rangi, analogicznych do Naczelnej Rady Ruskiej, powołanej w grudniu 1918 r. we Florynce. Dobrym przykładem w tej kwestii jest Polska Komisja Likwidacyjna w Krakowie, której cześć prasy przypisywała funkcję kondominium z Austrią. Jeden z kierowników Komisji, Zygmunt Lasocki, poczuł się zmuszony polemizować i przy tej okazji wyjaśniał:

Można PKL rozpatrywać jako przedstawicielstwo rządu polskiego w Warszawie lub rząd dzielnicowy, ale nie jako condominium z Austrią (Biblioteka Naukowa PAN i PAU, sygn. 4105).

Jest to trafne zdefiniowanie charakteru nie tylko krakowskiej Komisji, ale też, per analogiam, Naczelnej Rady Ruskiej. W jej wypadku należałoby użyć określenia: przedstawicielstwo rządu rosyjskiego, rząd dzielnicowy działający w imię Rosji. Na tym tle ocenić możemy relacje, jakie wytworzyły się między nią i jej agendami, a organami państwa polskiego. 
Teoretycznie istniały wtedy dla Łemkowyny jeszcze inne opcje, poza rosyjską: przynależność do odrodzonego państwa polskiego, już - jak można odczytać choćby z deklaracji prezydenta Wilsona i cesarza Karola I - od 1917 r. postulowanego przez mocarstwa, lub do państwa zachodnioukraińskiego, które deklaratywnie zaistniało na miesiąc przed wiecem we Florynce i posiadało pewne zasoby wojskowe, finansowe i organizacyjne. Obie opcje miały pewną liczbę zwolenników na Łemkowynie, przy czym aktywność polskich etnicznie środowisk $\mathrm{w}$ ruskich częściach powiatów podkarpackich stanowiła lokalną przeciwwagę dla działań łemkowskich chyba w większym stopniu niż analogiczna działalność ukraińska. Polityka polska miała też swoich zwolenników wśród Łemków, a mianowicie niektórych wójtów, wybranych jeszcze przed wojną („Łemkowszczyzna” 1919). Polityka ta nie od razu była skoordynowana. Władze wyznaczone przez Polską Komisję Likwidacyjną w Krakowie istniały równolegle $\mathrm{z}$ wciąż działającą administracją austriacką. Obie te administracje obsadzone były przez Polaków, ale między starostami a komisarzami Komisji Likwidacyjnej zdarzały się rywalizacje. Z oporami dawna austriacka żandarmeria, złożona $\mathrm{z}$ Polaków, przekształcała się w polską policję. Nie chciały ustąpić nowym radom organy samorządowe wybrane jeszcze za czasów habsburskich. Bywało, że organy wykonawcze rad polskich usuwały urzędników mianowanych jeszcze przez cesarza z powodu ich nadużyć względem ludności lokalnej lub niepewności, co do ich lojalności politycznej. Linie konfliktów w tej części Galicji były różne - czasem wyraźnie dzieliły społeczności etniczne czy narodowe między sobą, czasem wynikały z odmiennych interesów społecznych.

Warto tu przytoczyć dwa przykłady. Polska Organizacja Narodowa w Nowym Targu w sprawozdaniu dla Polskiej Komisji Likwidacyjnej w Krakowie donosiła 4 listopada 1918 r., że:

Ze względu na dobro i uspokojenie ludności zarządzono, by usunęli się natychmiast znienawidzeni przez ludność urzędnicy starostwa, jak starosta Stanisław Psarski, praktykant koncept. Mieczysław Solecki, inspektor zbożowy dr Franciszek Baluż i funkcjonariusze aprowizacyjni: Zygmunt Gawłowski, Mychajło Jaszan" (Biblioteka Naukowa PAN i PAU, sygn. 4175, k. 39).

Jak można sądzić $\mathrm{z}$ imienia, Jaszan był Ukraińcem, ale to nie jego etniczność, ale nadużycia były powodem wymuszenia na nim dymisji wraz z jego polskimi kolegami i przełożonym. Natomiast uprzedzeniami etnicznymi był 
po części uargumentowany anonimowy donos, jaki otrzymała Komisja Likwidacyjna cztery dni później z Krakowa:

Wysoka Rado Polska Narodowa! Mam zaszczyt donieść Wysokiej Radzie, ażeby łaskawie zwróciła uwagę na rasę Ruską, która aż za gęsto pozostała wzniesiona za czasów panowania Austriackiego w różnych Komendach i Urzędach i do tych czas pozostaje w nich a w najgorszym stopniu zgubne daje owoce dla kraju i narodu polskiego przez wykonywanie przeróżnych swoich machinacji prowokatorskich. Jako polak znieść tego niemogę, a zatem upraszam o łaskawe stwierdzenie stanu rzeczy (tamże, k. 72, ortografia i słownictwo zgodne z oryginałem).

Gdy chodzi o lokalnych działaczy polskich, to jest tych, którzy tworzyli rady w powiatach zamieszkanych częściowo przez Łemków, wielu z nich przejawiało tendencję do nawiązania kontaktów z przedstawicielami łemkowskimi. Było tak nie tylko w Grybowie, gdzie strukturami Polskiej Komisji Likwidacyjnej kierował prawnik i ziemianin Kazimierz Ramułt, czy w Gorlicach, gdzie marszałkiem Rady Powiatowej wywodzącej się jeszcze z czasów austriackich był przedsiębiorca naftowy Władysław Długosz, polityk polski wysokiej rangi, były austriacki minister a ówcześnie naczelnik Wydziału Rolnictwa Polskiej Komisji Likwidacyjnej w Krakowie. W Nowym Sączu, planując utworzenie Powiatowej Rady Narodowej, przewidziano 5 miejsc dla delegatów wsi łemkowskich. Jej działacze, Henryk Suchanek i Feliks Bulsiewicz, z zawodu urzędnicy kolejowi, zwracali ponadto uwagę Polskiej Komisji Likwidacyjnej na potrzebę wypracowania pozytywnego programu w sprawie łemkowskiej:

Zachodzi tylko wątpliwość i w ogóle niejasność naszego stosunku do Rusinów i w tym względzie zwracamy się niniejszym z prośbą do Polskiej Komisji Likwidacyjnej o możliwie rychłe informacje i wskazówki. W każdym razie sądzimy, że skoro w tutejszym powiecie istnieje około 40 wsi zamieszkałych przez ludność ruską (Łemkowszczyzna) to Rusini powinni mieć swoją reprezentację w Powiatowej Radzie narodowej, aby ta Rada nie była jakimś kadłubowym ciałem (Biblioteka Naukowa PAN i PAU, sygn. 4175, k. 33-35).

Wytyczne Wydziału Administracyjnego Polskiej Komisji Likwidacyjnej w Krakowie w sprawie stosunku do Rusinów zostały sformułowane, ale jedynie w postaci tymczasowego zarządzenia. Znamy je z brulionu odpowiedzi udzielonej w tej sprawie komisarzowi w Gorlicach, 27 grudnia 1918 r.: 
P. K. L. zastrzega do wyłącznie swojej decyzji regulowanie i załatwianie spraw narodowościowych w kraju, zawieranie umów wiążących obie strony, układanie warunków zgodnego współżycia i.t.d. a p. p. Komisarzy P. K. L. względnie ich zastępców ogranicza jedynie do szczegółowych i bezstronnych sprawozdań oraz do stawiania wniosków. [...] O ile idzie o warunki umowy z Rusinami powiatu gorlickiego P. K. L. nie może zatwierdzić pierwszego punktu takowej, odnoszącego się do uwolnienia Rusinów od obowiązku służby wojskowej, i poleca Panu, by w miarę jak zarządzenia dotyczące poboru i powołania zostaną wydane, stosował je bezwarunkowo i z całą ścisłością także do ludności ruskiej powiatu. W razie potrzeby do poparcia tych zarządzeń dodana Panu będzie asysta zbrojna. P. K. L. wychodzi w tym wypadku z założenia, że wszyscy poddani dawnego państwa austriackiego zamieszkali w granicach Galicji stali się obecnie poddanymi państwa polskiego i będą nimi tak długo póki nie uzyskają stąd uwolnienia, a przyjęcia do związku państwa obcego. $\mathrm{Z}$ jednej strony zatem mają Rusini powiatu tamtejszego prawo korzystania ze wszystkich praw obywatelskich, $\mathrm{z}$ drugiej jednak muszą ponosić wszystkie ciężary i obowiązki obowiązujące wszystkich poddanych państwa Polskiego (Biblioteka Naukowa PAN i PAU, sygn. 4177, k. 17).

Jak można z tego wnioskować, rzecz nie szła o samo istnienie rad łemkowskich i ich działalność terenową, mającą na celu utrzymanie ładu - bo przecież aprobowano podobną aktywność rad żydowskich - ale o kwestionowanie przez rady łemkowskie praw państwa polskiego do określonego terytorium. Optując za Rosją weszły one w konflikt polityczny z Polakami. Nie miał racji wspomniany już Kazimierz Ramułt, gdy odwołany w lutym 1919 r. z urzędu komisarza polskiego w Grybowie z powodu ugodowej postawy wobec Naczelnej Rady Ruskiej (Lasocki 1931, 57-58) pisał w odezwie do ludności powiatu:

Z gorącą podzięką zwracam się również do ludności ruskiej, powiat nasz zamieszkującej, do prezydium i całej rady ruskiej, nie mogąc przemilczeć, że lojalne stanowisko tejże wobec władzy polskiej, ułatwiało niczem niezmącone współżycie, utrzymanie ładu, spokoju i porządku (Biblioteka Naukowa PAN i PAU, sygn. 4179, k. 34).

Rady łemkowskie nie były lojalne wobec władzy polskiej, robiły co mogły, aby się od Polski odłączyć. Choć nie inicjowały starań o własną siłę militarną, nie weszły też w bliższe stosunki z ponadlokalnymi ośrodkami władzy polskiej. Nie doszło w Krakowie do przewidywanego w instrukcji Polskiej Komisji 
Likwidacyjnej „bezpośredniego porozumienia się z wylegitymowanymi reprezentantami” łemkowskiej narodowości. Jednorazową próbę rozmów ze stroną polską, ale w Warszawie, podjął Jarosław Kaczmarczyk w kwietniu 1919 r. Miał się tam spotkać z premierem Jędrzejem Moraczewskim oraz pułkownikiem Józefem Rybakiem w Ministerstwie Spraw Wojskowych. Usłyszał - ale tylko według jego relacji, której obaj polscy rozmówcy zaprzeczyli podczas procesu sądeckiego w 1921 r. - zapewnienie o wyłączeniu Łemków spod poboru do polskiego wojska i uznaniu samorządu łemkowskiego aż do czasu podjęcia decyzji o losach Łemkowyny przez konferencję pokojową (Когутов b.d., 6). Przekaz na ten temat nie jest klarowny, choć zgadza się z faktem, że 7 marca 1919 r. obrany właśnie Sejm Ustawodawczy uchwalił pobór do Wojska Polskiego w całym państwie. Jednak Moraczewski już od 16 stycznia nie był premierem. Być może Kaczmarczyk, tak go tytułując podczas zwołanego po powrocie z Warszawy posiedzenia Ruskiej Rady Narodowej w Grybowie, czynił to z uwagi na obyczaj. Spotkanie z Moraczewskim jako wicemarszałkiem Sejmu, bo taką wtedy pełnił funkcję, i tak było zasadne, gdyż to sejm uchwalił pobór. Jednak Hładyk, który towarzyszył Kaczmarczykowi w rozmowach warszawskich wspominał potem jedynie o konsultacjach w ministerstwie Spraw Wojskowych i datował je na luty 1920 r. (Archiwum Akt Nowych, Ministerstwo Spraw Zagranicznych, sygn. 322/3294, k. 61-63). Być może miały miejsce dwie podróże do Warszawy?

Czy wydarzenia na Łemkowynie w 1918 r. przyciągały uwagę obserwatorów zewnętrznych? Nic na to nie wskazuje. Owszem, w gabinetach rządowych Stanów Zjednoczonych, Wielkiej Brytanii i Francji, dyskutowano nad przyszłością wschodniej Galicji oraz Rusi Węgierskiej i mamy tego liczne świadectwa źródłowe. Ale nawet pomysły stworzenia osobnej republiki karpackoruskiej w wymiarze ponadłemkowskim nie cieszyły się poparciem czy choćby zainteresowaniem. Śledził je tylko ekspert polityczny pracujący dla rządu brytyjskiego - Lewis Namier (Ludwik Bernstein). Pochodził z rodziny polsko-żydowskiej, wychowany w majątku ziemskim rodziców w Galicji Wschodniej. Łączył silne emocje antypolskie (przeciwne poglądom rodziny) z konsekwentnym rusofilstwem oraz z przekonaniem, że nie tylko Rusini Karpaccy, ale także Ukraińcy są kulturowo tak bliscy Rosjanom, że winni podlegać państwu rosyjskiemu. W niesygnowanym, ale zgodnie jemu przypisywanym, memorandum z 9 grudnia 1918 r. rozpatrywał różne warianty przynależności państwowej Galicji Wschodniej, przychylając się do zdania, że na Sanie powinna przebiegać przyszła granica polsko-rosyjska. Jednocześnie rozważał możliwość utworzenia po obu stronach Karpat niepodległego państwa rusińskiego. Studiujący 
opracowanie Namiera pracownicy brytyjskiego Foreign Office, jednomyślnie odrzucili tę opcję, jako niepraktyczną, gdyż państwo takie według nich nie byłoby zdolne do samodzielnego istnienia (Regina-Zacharski 2004, 194).

Tu trzeba jeszcze wspomnieć jeden kontekst międzynarodowy sytuacji na Łemkowynie, to jest relacje działaczy karpackoruskich z „białą” Rosją. Działy się one w dwóch obszarach: emigracyjnym, to jest głównie zachodnioeuropejskim, oraz syberyjskim. Pierwszy z nich nie miał specjalnego znaczenia i ograniczył się do zwalczania przez rosyjskich emigrantów idei osobnego narodu ukraińskiego (Koutaïssoff 1918; Volkonsky 1920). Działacze karpackoruscy mieli także współpracować z Aleksandrem Izwolskim, rosyjskim dyplomatą rezydującym w Paryżu, który koordynował stamtąd działalność polityczną białej emigracji na Zachodzie („Agitacja na Łemkowszczyźnie”, 1919).

Wymierny skutek mogły mieć wydarzenia na wschodzie Rosji. Rusini z Galicji znaleźli się na Syberii i Dalekim Wschodzie w rozmaitych okolicznościach pierwszej wojny światowej, najczęściej jako jeńcy z armii austro-węgierskiej lub emigranci polityczni. Tworzyli tam w latach 1917-1919 Komitety Karpackoruskie, podporządkowane Centralnej Radzie Karpackoruskiej (Центральний Карпаторусский Совет) w Omsku, której przewodniczył A[drian?] Коруstianski. Rada ta zaprotestowała przeciw przynależności Rusi galicyjskiej do Polski, a w czerwcu 1919 r. wzywała wszystkich karpackich Rusinów od 18. do 40. roku życia, przebywających na Syberii, do włączania się w szeregi wojska karpackoruskiego (Копистянский, Скицко, 1919). Stanisław Walicki, sekretarz Konsulatu RP we Władywostoku, w raporcie dla Poselstwa RP w Tokio, pisał w październiku 1921 r., że istniała łączność pomiędzy akcją karpackoruską na Syberii a diasporą w Kanadzie oraz Komitetem Karpackoruskim w Paryżu. Wskazywał także na poparcie udzielane przez działaczy czechosłowackich. Václav Girsa, pełnomocnik czechosłowacki na Dalekim Wschodzie, wydawał „świadectwa legitymacyjne” Rusinom z Galicji (Archiwum Akt Nowych, Poselstwo RP w Tokio, sygn. 1, k. 1-8). Ministerstwo Spraw Wewnętrznych omskiego rządu Aleksandra Kołczaka (uznawanego przez państwa zachodnie za rząd rosyjski) wydało 15 maja 1919 r. i ogłosiło w swoim urzędowym organie oświadczenie, że likwiduje na wyzwolonych spod władzy bolszewickiej ziemiach Rosji filie Ukraińskiego Centralnego Komitetu Galicyjsko-Bukowińskiego, a na ich miejsce uprawomocnia kompetencje Centralnej Rady Karpackoruskiej. Miały one polegać między innymi na rejestracji i wydawaniu poświadczeń osobom urodzonym na Rusi Karpackiej, to jest w Galicji, na Bukowinie i Rusi Węgierskiej (Урядовий вистник 1919; „Колчак і сибірське 
українцї" 1919, 3). Jak jednak wiemy, Kołczak w listopadzie 1919 r. przegrał wojnę z bolszewikami i w styczniu kolejnego roku złożył rezygnację z funkcji Naczelnika Państwa Rosyjskiego. Do podobnej współpracy Rusinów Karpackich z „białą” Rosją doszło również na południu Rosji, gdzie w szeregach Armii Ochotniczej generałów Ławra Korniłowa i Antona Denikina walczył Oddział Karpackoruski (Ваврик 1934; Kedryn 1937). Rodzący się w ten sposób czynny sojusz Karpackich Rusinów z Rosją nie przyniósł spodziewanych efektów politycznych wskutek przegranej kontrrewolucjonistów.

Spośród delegatów wyznaczonych w Winnipegu, tylko Hładyk pojechał do Europy, wspomagany przez dwóch wysłanników Rusinów amerykańskich. Poza intensywną działalnością na Łemkowynie, nawiązał także kontakty polityczne w Paryżu i Warszawie. Co do jego poczynań paryskich w 1918 r. można powiedzieć tylko to, że nie wykroczyły poza szczebel emigracyjnych polityków rosyjskich i rusofilskich. Współczesny mu ukraiński działacz religijny i narodowy w Kanadzie, ks. Pantelejmon Bożyk, ironizował potem, że:

Hładyk w Paryżu niczego nie zrobił. Mówiono, że on tam nawet nie umiał znaleźć tej ulicy, która prowadziła do tego domu, w którym zasiadali przedstawiciele państw Ententy. Po ciężkim trudzie dostał się do tego domu, ale swego memoriału prezydentowi narad nie wręczył, ale tylko kilka razy zaglądnął przez dziurkę w drzwiach do sali, w której zasiadali przedstawicie państw Ententy i na tym jego misja skończyła się [...] Jedyne, co Hładyk w Paryżu zrobił, to to, że poskarżył się halickiemu moskalofilowi Markowowi na rosyjskich biskupów, na Jewdokima i Aleksandra, przedstawił ich mu, jak takich, którzy chłodno odnoszą się do galicyjskich moskalofili w Ameryce i nie chcą popierać ruchu rusofilskiego (Божик 1927, 152-153).

Prześmiewcza relacja ks. Bożyka była zgodne z prawdą tylko w jednym działacze łemkowscy nie dostali się przed oblicze najważniejszych decydentów, zresztą tak samo jak delegacja ukraińska, która siedziała w Paryżu zupełnie jałowo w tym samym czasie co Hładyk, wysuwając w swych memoriałach żądanie przyłączenia Łemkowyny do Ukrainy (Żurawski vel Grajewski 1995, 21). Rząd praski wysłał do Paryża także Antonija Beskyda, jako członka delegacji karpackoruskiej, w której skład weszli również działacze ze Stanów Zjednoczonych, w tym Grigorij Żatkowycz, przewodniczący Rady Narodowej Amerykańskich Rusinów i główny partner polityczny rządu praskiego. Oni też nie zostali wezwani na obrady konferencji, a jedynie odbyli konsultacje we francuskim Ministerstwie Spraw Zagranicznych (Magocsi 1978, 91-96; Zięba 
1998, 201-207). Polityczne postulaty łemkowskie reprezentował w Paryżu Markow, pozostający w bliskich kontaktach z tamtejszymi kręgami rosyjskiej „białej” emigracji. To on ułożył kolejny memoriał (Markoff 1919), powtarzający tezy uchwał Pierwszego Kongresu Ruskiego w Kandzie i rad łemkowskich, łącznie $\mathrm{z}$ argumentacją historyczną, który został przekazany obradującym delegacjom. Amerykański ekspert Robert Howard Lord ujawnił polskiemu ekspertowi, Eugeniuszowi Romerowi, że Markow, jako przedstawiciel galicyjskich rusofilów, był konsultowany przez Komisję ds. Polskich, zajmującą się w czasie konferencji pokojowej sprawą wschodniej Galicji (Romer 1989, 356).

Co do Hładyka, wiemy że był w paryskiej delegaturze American Relief Administration, czego skutkiem była późniejsza (czerwiec 1919 r.) misja rozpoznawcza na Łemkowynie jej delegata lwowskiego Meriana C. Coopera (Delegat amerykański w Krynicy 1919, 1). Opublikował też w Paryżu broszurę w języku angielskim przeciw Polsce (Hladick 1919). W Warszawie odwiedził poselstwo brytyjskie i zostawił tam petycję parafii greckokatolickiej w Czarnem, czyli ks. Jurczakewicza, przewodniczącego Naczelnej Rady Łemkowyny. W Londynie trafił do rosyjskiej parafii prawosławnej (Russian Orthodox Church of The Assumption and All Saints) i dostarczył informacje o sytuacji Kościoła prawosławnego w Polsce, głównie o likwidacji przez władze polskie niektórych monumentalnych soborów prawosławnych, wzniesionych za caratu w dużych miastach polskich celem ich rusyfikacji. Duchowni z tej parafii, powołując się na Hładyka, skarżyli się potem (1920 r.) obradującemu w Londynie światowemu zgromadzeniu biskupów anglikańskich (Lambeth Conference) na tę derusyfikację etnicznych ziem polskich, uważając ją za krzywdę Kościoła rosyjskiego, spowodowaną przez „fanatycznych jezuitów”. W doniesieniu duchownych prawosławnych mowa była także o zabraniu przez Polskę „Russian partion of Galicia” a nawet „parts of Besarabia”, jako ziem przynależnych Rosji (Church of England Lambeth Palace Library, Douglas Papers, vol. 58, k. 1-11).

Jak działają „młyny historii", czyli rywalizacja terytorialna Polski i Czechosłowacji w 1919 roku a łemkowskie wysiłki polityczne

Gdy upadała nadzieja na wielką Rosję od Popradu do Kamczatki, ukierunkowanie politycznych dążeń Łemków z wolna ulegało zmianie ku federacji z Czechosłowacją w ramach jej planowanego trzeciego członu, czyli Rusi Podkarpackiej. Łemkowscy emisariusze na terenie Słowacji (Jarosław Kaczmarczyk, 
Dymytryj Wysłockij, Andrij Gagatko) już w grudniu 1918 r. utworzyli tam Radę Łemków i podjęli współpracę z Antonijem Beskydem, przywódcą Rusinów na Preszowszczyźnie. Rozmawiali m.in. z Milanem Hodžą, członkiem Słowackiej Rady Narodowej i współtwórcą Czechosłowacji. Działacze ukraińscy twierdzili, że winę za antyukraiński i proczechosłowacki kurs na Preszowszczyźnie ponosi właśnie tych „tylko kilka jednostek, które przyszły z galicyjskiej Łemkowszczyzny i wciągnęly między siebie Beskyda" (Ортоскоп 1924, 12-13). Równolegle Markow przedstawiał swe koncepcje prezydentowi Masarykowi, ujmując całość ziem zamieszkałych przez Rusinów w Galicji, łącznie z Łemkowyną, jako potencjalne nabytki Czechosłowacji. W kolejnych miesiącach kierowana przez Beskida Karpackoruska Rada Narodowa słała do Pragi memoriały, postulując zajęcie wojskowe Podkarpacia i Łemkowyny (Симоненко 1957, 61).

Jeszcze 1918 roku napłynęły do Polskiej Komisji Likwidacyjnej pierwsze raporty o pojawieniu się dywersji czechosłowackiej na Łemkowynie. W grudniu w Piwnicznej patrol czechosłowacki wziął do niewoli polskiego żandarma (Biblioteka Naukowa PAN i PAU, sygn. 4177, k. 32). Polacy szybko przedsięwzięli kontrakcję, sugerując poprzez doniesienie prasowe prowadzenie konsultacji między przedstawicielami Rusinów z okręgu lubowelskiego na Spiszu a polską Organizacją Narodową w Nowym Sączu na temat przyłączenia do Polski przy zachowaniu swobody wyznania greckokatolickiego i nauki szkolnej w języku ruskim („Rusini”, 1918). Czy rodzący się zatarg o Łemkowynę między Polską a Czechosłowacją miał związek z opisanymi wyżej zabiegami Rady Łemków?

Prezydent Masaryk nie należał do wrogów Rosji ani Ukrainy (Бочковський 1930; Kutina, Saizu 1969). W trakcie wojny ukraińsko-polskiej o Lwów jego rząd podjął współpracę ekonomiczną z władzami zachodnioukraińskimi w Stanisławowie. Praga była przeciwna przyłączeniu Galicji Wschodniej do Polski. Rozpuszczane były też pogłoski o ewentualnym przejęciu tego regionu przez Czechosłowację (Lewandowski 1974, 63-185). Ten kurs uprawdopodobniał nadzieje Łemków na powodzenie ich starań o znalezienie się pod jej panowaniem. Na Łemkowynie wzmogła się zbrojna dywersja czechosłowacka. Równolegle trwała brutalna pacyfikacja skupisk polskich po południowej stronie Karpat. Najwyraźniej oba kierunki działań Pragi były ze sobą skorelowane. 18 stycznia 1919 r. Lasocki w imieniu Komisji Rządzącej powiadomił Prezydium Rady Ministrów w Warszawie, że czechosłowackie oddziały pograniczne zachęcają Rusinów w powiatach sądeckim, grybowskim, gorlickim, jasielskim i krośnieńskim, aby domagali się przyłączenia tych ziem do Czechosłowacji (Biblioteka Naukowa PAN i PAU, sygn. 4177, k. 47-48). W lutym 
alarmowała „Gazeta Warszawska”, wzmiankując ambicje czeskie „w kierunku wschodnim, na ziemie rusińsko-węgierskie, a nawet na Podkarpacie galicyjskie (t.zw. Łemkowszczyznę)" (Niebezpieczeństwo, 16). W tym samym czasie Lasocki raportował polskiemu Ministerstwu Spraw Zagranicznych o licznych aresztach i internowaniach Polaków na Orawie i Spiszu, rewizjach w polskich plebaniach, rekwizycjach bydła, rabunkach sklepów i gospodarstw, zwłaszcza tych, które należały do wójtów polskich gmin wiejskich, ostrzeliwaniu wsi po polskiej stronie Dunajca, napaściach na polskich rybaków, ogłuszaniu i zabijaniu granatami ryb w Dunajcu i Popradzie (Biblioteka Naukowa PAN i PAU, sygn. 4177, k. 34-36). Była to próba zastraszenia zwolenników przyłączenia polskich obszarów Spisza i Orawy do państwa polskiego. Strona polska podjęła z kolei środki przymusu mające wyperswadować Łemkom współpracę z Czechosłowacją. Trwała niewypowiedziana oficjalnie wojna pograniczna. Dywersja czechosłowacka wzdłuż karpackiego odcinka południowej granicy Polski odbiła się bardzo silnym echem w polskiej opinii publicznej. Z biegiem czasu prasa polska donosiła o prawdziwych i rzekomych napaściach czeskich na terytorium zachodniej Galicji. Na samym początku lutego 1919 r. ukazały się nawet doniesienia o wtargnięciu wojsk czeskich do Nowego Targu (Romer 1989, 159; „Machinacje na Łemkowszczyźnie” 1919; „Agitacja na Łemkowszczyźnie”, 1919; Niebezpieczeństwo, 1920, 33-35).

W rzeczywistości politycy czescy grali kartą łemkowską tylko lokalnie. Na forum konferencji pokojowej w Paryżu apetyty na jakikolwiek obszar na północ od Karpat, zwłaszcza w zachodniej Galicji, raczej nie mogły Czechosłowacji przynieść popularności. Polska delegacja była wręcz ucieszona z doniesień o „agresywności Czechów, którzy teraz nie tylko Nowy Targ, ale nawet Nowy Sącz już zajęli", jak w lutym 1919 r. żartował jeden z jej kierowników, Józef Wielowieyski (Romer 1989, 166). Podczas pertraktacji nad kwestią karpackoruską, polityczną wymowę miały nie elaboraty samych Rusinów, ale to, co mówiła najwyższym kręgom decydenckim delegacja Czechosłowacji. To ona przejęła oficjalnie funkcję adwokata Rusinów. Mogła się w tym zakresie posługiwać deklaracjami przygotowanymi w 1918 r. po rusku i w językach zachodnich (Меморандумъ Народнаго Совета Русскаго Прикарпатя 1918; Beskid, Sobyn 1919), ale tego nie zrobiła, jak można przypuszczać, dlatego, że zawierały postulaty zbyt kłopotliwe politycznie, odnoszące się do przynależności państwowej Łemkowyny. Zabiegając w Paryżu o przyłączenie Rusi Węgierskiej, częściowo do Słowacji, częściowo w formie osobnego kraju autonomicznego, minister spraw zagranicznych Edvard Beneš sprzeciwił się postulatowi 
włączenia do Czechosłowacji także Łemkowyny. Wprawdzie opowiadał się za tym premier Karel Kramár, ale tracił on w tym czasie znaczenie polityczne. Stanowisko Beneša poparł Żatkowicz (Żurawski vel Grajewski 1995, 49, 103). Podczas długiej dyskusji, która odbyła się 29 kwietnia 1919 r. w Pradze między prezydentem Masarykiem i Zygmuntem Lasockim, wtedy członkiem Komisji Rządzącej dla Galicji i Śląska Cieszyńskiego we Lwowie, ani razu nie padła nazwa Łemkowyny, ani też żadna aluzja do niej. Poruszano wiele konfliktowych kwestii pogranicznych, omawiany był po kolei każdy zatarg, jednak Rusini po północnej stronie nie interesowali prezydenta Czechosłowacji, który według polskiego rozmówcy miał być gotów na ustępstwa w wielu miejscach granicy w zamian za polskie wycofanie się ze Śląska Cieszyńskiego (Biblioteka Naukowa PAN i PAU, sygn. 4176). Postawy Beneša i Masaryka to klucz do interpretacji działań czechosłowackich po północnej stronie Karpat na obszarze zamieszkałym przez Łemków. Te działania miały charakter taktyczny. Stanowiły rodzaj pogróżki wobec Polski, czy też presji na jej stanowisko w kwestii śląskiej, sugestię, że Czechosłowacja może zmaksymalizować swoje pretensje terytorialne. Oficjalnie jednak Praga ani się nie zająknęła na temat swoich aspiracji do Łemkowyny. Nie odniosła się też do treści listu, wysłanego w maju przez działaczy łemkowskich w imieniu Karpackoruskiej Rady Narodowej w Preszowie do prezydenta Wilsona, w którym oznajmiali, że reprezentują:

naród ruski, mieszkający w północnych komitatach byłych Węgier i w południowych częściach powiatów politycznych prowincji austro-galicyjskiej, potępiali separatyzm ukraińskich polityków jako antysłowiański, antykulturalny i antyspołeczny oraz płód austro-węgierskiego imperializmu i oznajmiali całemu światu cywilizowanemu, że uważają siebie za autonomiczną, ruską cześć republiki czechosłowackiej (cyt. za: Ортоскоп 1924, 16).

Rację więc mają dwaj historycy czescy, Zdenek Sladek i Jaroslav Valenta, pisząc:

W materiałach praskiego MSZ z lat 1919-1920 nie można znaleźć żadnych śladów dyplomatycznych [poparcia dla Łemków]. Tak samo pozostały bez echa kilkakrotnie powtarzane na wiosnę 1919 roku memoriały i petycje podawane za pośrednictwem [...] preszowskiej Rady. [...] Dyplomacja czechosłowacka [...] bynajmniej nie zamierzała angażować się w dość naiwnie konstruowane żądania i, o ile można stwierdzić na podstawie materiałów archiwalnych, nie nadała tym petycjom biegu urzędowego w Paryżu (Sladek, Valenta 1968, 152). 
Cztery dokumenty międzynarodowe przesądziły o losie Łemkowyny i pozbawiły działania Łemków doraźnego sensu politycznego.

Pierwszym była decyzja Rady Ministrów Spraw Zagranicznych podjęta 25 czerwca 1919 r., upoważniająca Polskę do cywilnego rządu na terenie Galicji Wschodniej. Była to faktyczna zgoda na wojskowe i cywilne opanowanie całej Galicji aż po rzekę Zbrucz. Traktat między Głównymi Mocarstwami Sprzymierzonymi i Stowarzyszonymi a Polską, zwany małym traktatem wersalskim, podpisany w Wersalu 28 czerwca 1919 r., wprawdzie nie określił losu ziem należących poprzednio do Austrii, ale przyznał Polsce jurysdykcję nad ich mieszkańcami. Odnośne sformułowanie (rozdział I, artykuł 3) brzmiało:

Polska uznaje za obywateli polskich z samego prawa i bez żadnych formalności tych obywateli niemieckich, austriackich, węgierskich lub rosyjskich, którzy w chwili uzyskania przez Traktat niniejszy mocy obowiązującej posiadają stałe zamieszkanie na terytorium uznanym lub które będzie uznane za część składową Polski (Sierpowski 1989, 126).

To sformułowanie legitymizowało m.in. pobór do wojska i podatki nakładane na Łemków, gdyż żadne z mocarstw, z którymi Polska zawarła traktat, nie kwestionowało de facto ani de iure władzy polskiej na terenie Galicji zachodniej, pozostawiając w zawieszeniu tylko ostateczny los Galicji wschodniej.

Traktat pokojowy z Austrią, podpisany 10 września 1919 r. w St. Germain-en-Laye, którego jedną ze stron była także Polska, w sekcji trzeciej zatytułowanej Państwo Czechosłowackie, w artykule 53 postanawiał:

Austria, zgodnie z działaniami już podjętymi przez Mocarstwa sprzymierzone i stowarzyszone, uznaje całkowitą niezależność państwa czesko-słowackiego, które obejmie autonomiczne terytorium Rusinów na południe od Karpat (Sierpowski 1989, 140).

Łemkowskie starania o przyłączenie do Czechosłowacji traciły rację bytu. Granice Czechosłowacji na linii Karpat były przesądzone w stosunkach międzynarodowych, podobnie jak zasięg terytorialny zasiedlenia Rusinów, którzy mogli się w tych granicach zmieścić. Łemkowyna leżała przecież na północ od Karpat. Mimo to, działacze łemkowscy nie rezygnowali i nawet po traktacie z St. Germain-en-Laye uparcie twierdzili, że sprawa przynależności ich lokalnej ojczyzny nie jest przesądzona. Odnowienie formuły rad nastąpiło 12 marca na wiecu we Florynce, gdy wybrano Zwierzchnią Radę Łemkowskiej Rusi 
i jej Komitet Wykonawczy (mylnie zwany rządem). Ponieważ w tym czasie trwała wojna polsko-sowiecka, krok ten, jak też przede wszystkim opór przed poborem (Gąsiorowska-Grabowska 1964, 134-135; Horbal 1997, 76-81), wyglądał na dywersję na tyłach frontu. Nie można było wykluczyć wpływu agitacji bolszewickiej, gdyż istniały wśród Łemków sympatie do Rosji Sowieckiej (Ваврик 1961; Дуркот 1934).

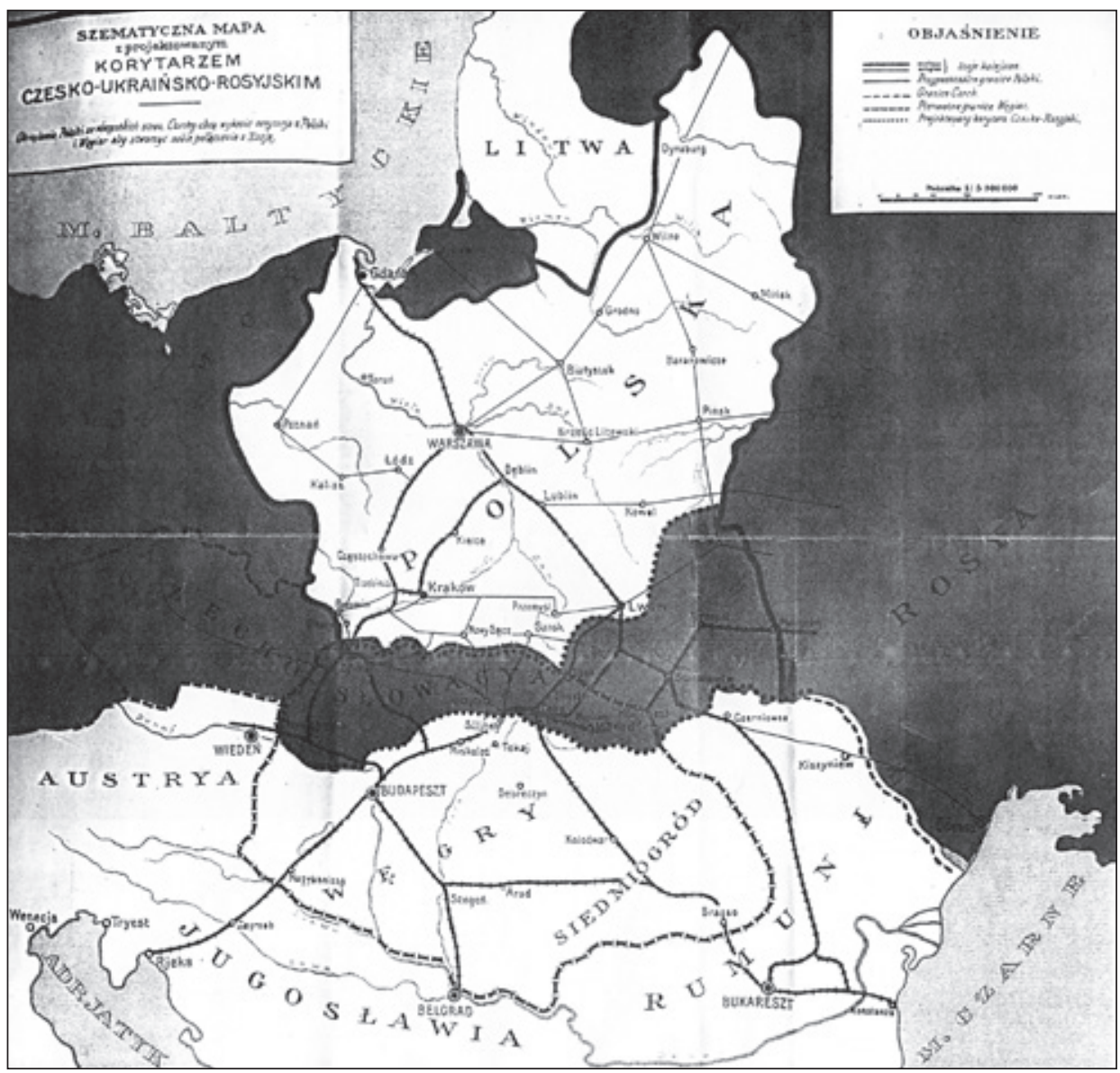

Mapa obrazująca zasięg terytorialny tzw. korytarza rosyjsko-czechosłowackiego, obejmującego Łemkowynę wg autorów broszury Niebezpieczeństwo korytarza czesko-rosyjskiego z $1920 \mathrm{r}$.

W tym czasie Węgry podjęły ostatnią próbę utrzymania Rusi Karpackiej. W Polsce na rzecz ich interesów wytrwale lobbował Dąbrowski. Wyrazem tego była seria jego artykułów, zebranych i wydanych na początku 1920 r. 
w broszurze pt. Niebezpieczeństwo korytarza czesko-rosyjskiego. Konieczność granicy polsko-wegierskiej. Wywodził w niej, że „wspaniały, lasami uwieńczony łańcuch Karpat tworzył przez cały ciąg historii najbezpieczniejszą granicę między obydwoma tymi krajami”, ambicje czechosłowackie na tym odcinku to wynik „niepomiernej chciwości” i „nie ulega wątpliwości, że Polska miałaby spokojną i pewną granicę od południa, gdyby sąsiadowała bezpośrednio z Węgrami”. Chodziło mu o zagrożenie w postaci terytorialnego połączenia Czechosłowacji z Rosją dzięki zajęciu fragmentów Galicji przy jednoczesnym opanowaniu jej wschodniej części przez Rosję. Sojusz Czechosłowacji z „imperialistyczną i panslawistyczną” Rosją nazywał „piekielnym planem [...] pozbawionym zresztą wszelkiej zarówno historycznej, jak etnograficznej podstawy" i uznawał za godzący w najżywotniejsze interesy Polski. Do broszury dołączona została schematyczna mapa, pokazująca graficznie te groźne skutki utworzenia korytarza, który Dąbrowski nazwał: „czesko-ukraińsko-rosyjskim” (Niebezpieczeństwo, 3-4). Z tego powodu poruszał też wątek łemkowski, dowodząc, że w pozostającym pod czeską kontrolą Użhorodzie tworzy się ośrodek antypolskiej agitacji wśród Łemków, który upowszechnia opinię, że:

Chociażby konferencja pokojowa przyznała Łemkowszczyznę Polsce, to Łemki nie będą nigdy obywatelami Państwa Polskiego. Łemki głęboko wierzą, że będą przyłączeni do Rosji, wierzą, że Rosja stanie na nogi i zabierze Łemkowszczyznę. Jeżeli by to okazało się niemożliwem, to wówczas Łemkowszczyzna przyłączona będzie jako autonomiczna Ruś Karpacka do czesko-słowackiej republiki (Niebezpieczeństwo 1919, 104).

4 czerwca 1920 r. stanowił ostateczny koniec marzeń o wejściu Rusi łemkowskiej w skład Czechosłowacji. W tym dniu w pałacu Grand Trianon w Wersalu podpisany został traktat pokojowy z Królestwem Węgierskim, który oznaczał jego rozbiór (Text of the Treaty, 1920). Ponieważ Czechosłowacja i Polska były stronami tego traktatu i uzyskały na jego mocy części przedwojennego terytorium Węgier (Czechosłowacja całe Górne Węgry razem z Rusią Karpacką, a Polska - na mocy decyzji komitetu arbitrażowego utworzonego na mocy traktatu - małe skrawki na Spiszu i Orawie), traktat ten określił także przebieg granicy polsko-czechosłowackiej w najbliższym sąsiedztwie Łemkowyny oraz kształt terytorialny Rusi w obrębie państwa czechosłowackiego. Kontynuowanie opcji czechosłowackiej przez polityków łemkowskich z tym 
dniem straciło sens, choć nadal organizacje karpackoruskie w diasporze prowadziły lobbing polityczny wymierzony przeciw Polsce (Memorandum 1921; Zięba 1998, 208-209).

\section{Znaczenie wydarzeń lat 1918-1921: Łemkowie stają się narodem}

Łemkowskie działania polityczne w latach 1918-1920 nie miały większego znaczenia w stosunkach międzynarodowych. Nie zainteresował się nimi żaden z przywódców wielkich państw, decydujących o losach Europy w pierwszej wojnie światowej, ani licząca się w głównym nurcie życia politycznego prasa. Głos Łemków nie został dosłyszany w Paryżu podczas obrad konferencji pokojowej, a broszurki propagujące ich program polityczny wydane po francusku i angielsku zginęly bez śladu w natłoku literatury propagandowej, którą Paryż był w tym czasie zalany. Prorosyjskość Łemków nie na wiele przydała się Rosji, bo ta, upadając, mogła już tylko marzyć o imperialistycznych granicach, które podchodziłyby pod Nowy Sącz. Dosłownie na moment i na drugim planie opcja czechosłowacka zdołała skomplikować stosunki między Pragą a Warszawą. Dywersja w dobie wojny polsko-bolszewickiej nie miała większego znaczenia. Nie osłabiła sił militarnych Polski, bo Łemkowyna nie dysponowała znaczącym potencjałem demograficznym. Odmowa dania rekruta była więc tylko demonstracją polityczną, a ponieważ front inaczej niż w czasie pierwszej wojny światowej nie dotarł na jej obszar, antypolska postawa ludności cywilnej nie zyskała realnych wymiarów.

Czy to znaczy, że Łemkowie działali bez wymiernego skutku, zaś ich rady wiejskie, deklaracje wiecowe i przedsięwzięcia emisariuszy politycznych były czczą ruchliwością? Taki sąd byłby niesłuszny z kilku powodów. Wydarzenia tego okresu były zaledwie preludium samodzielnego ruchu narodowego i trzeba je oceniać, uwzględniając ten fakt. Już tylko to, że takie preludium zaistniało było sukcesem. Tym większym, że potencjał polityczny Łemków w 1918 r. był bardzo słaby. Nie posiadali doświadczonych liderów. Żaden z tych działaczy, którzy byli czynni w latach 1918-1921 nie miał stosunków na bliższej i dalszej arenie międzynarodowej. Wiejscy księża, studenci i małomiasteczkowi adwokaci takich liderów nie byli w stanie zastąpić. Stąd brały się nieuchronne błędy, jak na przykład zawierzenie politykom czechosłowackim i niewykorzystanie swego programowego antyukrainizmu jako atutu w stosunkach z Polską. To drugie nastąpi dopiero pod koniec lat 20. W toku 
wypadków z lat 1918-1921 została przetestowana istniejąca blisko pół wieku wizja Łemkowyny jako części wielkiej Rusi. Nie zanikła wprawdzie pod wpływem klęsk, ale rodzić się począł nowy sposób patrzenia na wspólnotę, jako samodzielną, istniejącą też bez Rosji, nieprzyporządkowaną jako dodatek do jakiejś większej tożsamości. Udział w wypadkach przełomowego dla tej części Europy okresu, wyniesione $\mathrm{z}$ nich doświadczenia, a następnie mit rodzący się na ich bazie odegrały i nadal odgrywają zasadniczą rolę w kształtowaniu się łemkowskiej tożsamości.

Skutki tożsamościowe wydarzeń z lat 1918-1921 ujawniły się także w diasporze na obszarze Stanów Zjednoczonych i Kanady. Wraz z napływem nowych emigrantów $z$ Łemkowyny, uczestniczących w powojennych działaniach politycznych, zrodził się tam ruch społeczno-kulturalny występujący pod sztandarami łemkowskimi. Od początku lat dwudziestych w kilku miastach amerykańskich, a nieco później też kanadyjskich, zaczęły powstawać Komitety Łemkowskie. Rozproszonych po rozległych obszarach kontynentu północnoamerykańskiego emigrantów łączyła lektura gazet wydawanych przez Hladicka - „Prawdy” (Oliphant) i „Łemkowyny” (Nowy Jork), której redakcję przejęli inni uczestnicy zmagań politycznych w starym kraju - Symeon Pyż i Dymytrij Wysłocki (Wanio Hunianka). Periodykiem wyraźnie określającym się jako łemkowski był miesięcznik (z czasem dwutygodnik) „Łemko” (Nowy Jork, potem Filadelfia). Nowe czasopismo deklarowało się jako organ narodowy i odwoływało do tożsamości łemkowskiej. W listopadzie 1928 r. nowojorski Komitet Łemkowski zorganizował Zjazd Ludowy w pomieszczeniach Ruskiego Klubu w Nowym Jorku, na który zaproszono delegatów wszystkich podobnych klubów, bractw, parafii, czytelni i komitetów. W enuncjacjach programowych z jednej strony pokreślona została odmienność ideowa względem ogólnoruskiego „Amerykansko-Russkiego Wiestnika”, czyli właśnie kierunek łemkowski („Отъ редакции” 1928, 2; „Нродный съђздъ” 1928, 3), z drugiej nadal trwało przekonanie o byciu zachodnią rubieżą „narodu ruskiego”, odżegnywano się od „wszelkiego separatyzmu” (Пиж 1928, 3-4) i deklarowano obronę interesów terytorialnych państwa rosyjskiego. Jeszcze w $1944 \mathrm{r}$., tuż przed końcem drugiej wojny światowej, Hładyk deklarował koncepcję, zgłaszaną na wiecach łemkowskich w latach 1918-1920, proponując wystosowanie do mocarstw memorandum $\mathrm{z}$ postulatem włączenia Łemkowyny do Rosji, razem ze wszystkimi ziemiami zaliczanymi przez niego do Rusi Karpackiej (Гладик, 1944). Apogeum tej fazy przemian narodowych, którą można nazwać pre-niepodległościową, było powstanie w Winnipegu w 1929 r. 
organizacji pod nazwą Łemko-Sojuz, której przewodniczącym został Teodor Kochan, uczestnik Pierwszego Ruskiego Kongresu w Winnipegu w 1917 r. („Коротка история Лемко-Союза”).

\section{Bibliografia}

\section{Źródła archiwalne}

Archiwum Akt Nowych w Warszawie

sygn. 322/3294, Ministerstwo Spraw Zagranicznych.

sygn. 1, Poselstwo RP w Tokio.

sygn. 104, Centralna Agencja Polska w Lozannie.

Biblioteka Naukowa PAN i PAU w Krakowie, Dział Zbiorów Specjalnych sygn. 4078, 4105, 4174-4177, 4179, 4254.

Church of England Lambeth Palace Library w Londynie Douglas Papers, vol. 58

Opracowania

Address of President Woodrow Wilson to the U.S. Senate 22 January 1917. Dostęp: 20.12.2018. https://www.firstworldwar.com/source/peacewithoutvictory.htm.

Beskid, Anton, Sobyn, Dmytryj. 1919. The Origin of the Lems Slavs of Danubian Provenance. Memorandum to the Peace Conference Concerning their National Claims. Prešov [-Paris]: National Council of Carpathian Russian.

Cavaleri, Ottavio. 1990. L'Archivo di Mons. Achille Ratti Visitatore Apostolico e Nunzio a Varsovia 1918-1921. Inventario. A cura di Germano Gualdo. Città dell Vaticano: Archivio Vaticano.

„Delegat amerykański w Krynicy”. 1919. Nowa Reforma, 11.06.1919.

G. 1919. „Agitacja na Łemkowszczyźnie (od spec. korespondenta wojennego)”. Kurier Polski, 29.03.1919.

Gąsiorowska-Grabowska, Natalia, et al. 1964. Dokumenty i materiały do historii stosunków polsko-radzieckich, t. 3: Kwiecień 1920-marzec 1921. Warszawa: Polska Akademia Nauk, Pracownia Historii Stosunków Polsko-Radzieckich, Akademia Nauk ZSRR, Instytut Słowianoznawstwa.

[Habsburg-Lothringen] Karol. 1918. „Do moich wiernych austriackich ludów”. Gazeta Lwowska, 19.10.1918.

Hladick, P. Victor. 1919. The Brutal Polish Persecutions in Lemkowskaya Russia. Paris.

Horbal, Bogdan. 1997. Działalność polityczna Łemków na Łemkowszczyźnie 1918-1921. Wrocław: Wydawnictwo Arboretum.

Janusz, Bohdan. 1915. 293 dni rządów rosyjskich we Lwowie (3 IX 1914 - 29 VI 1915). Lwów: Księgarnia Polska Bernarda Połonieckiego. 
Kedryn, Iwan. 1937. „W poszukiwaniu metryki. Kilka dat i faktów z dziejów powojennego moskalofilstwa galicyjskiego". Biuletyn Polsko-Ukraiński 6, nr 45: 3-4.

Koutaïssoff, A. 1918. Ukraina. Copenhagen.

Kutina, Zdeněk, Saizu, Ioan. 1969. Cesta T. G. Masaryka do Jasŭ. „Slovenský přehled”, 41.

Lasocki, Zygmunt. 1931. Wspomnienia szefa administracji P. K. L. i K. Rz. Kraków: nakładem autora.

Lewandowski, Krzysztof. 1974. Sprawa ukraińska w polityce zagranicznej Czechosłowacji w latach 1918-1932. Wrocław: Zakład Narodowy im. Ossolińskich.

„Machinacje na Łemkowszczyźnie”. 1919. Głos Narodu, 27.02.1919.

Magocsi, Paul Robert. 1976. “The Political Activity of Rusyn-American Immigrants in 1918”. East European Quarterly 10, no 3: 147-165.

Magocsi, Paul Robert. 1978. The Shaping of a National Identity. Subcarpathian Rus' 1848-1948. Cambridge, Mass. - London: Harvard University Press.

Magocsi, Paul Robert. 1993. “The Ukrainian Question Between Poland and Czechoslovakia: The Lemko Rusyn Republic (1918-1920) and Political Thought in Western Rus'-Ukraine”. Nationalities Papers 21, no 2: 95-105. https://doi.org/10.1080/ 00905999308408278.

Markoff, Dmitrij. 1919. Mémoire sur les aspirations nationales des Petits-Russiens de l'ancient emire austro-hongrois. [Paris].

Markoff, Dymitry. 1920. "The Ruthenians in Bukovina. Letter from the «Comité Carpatho-Russe»”. Document du Conseil, vol. 4.

Martynowych, T. Orest. 1991. Ukrainians in Canada. The Formative Period, 1891-1924. Edmonton: Canadian Institute of Ukrainian Studies Press.

Memorandum of the Carpatho-Russian Council in America Concerning Eastern Galicia with Lemkowschina and Bukowina. 1921. New York: Carpatho-Rusyn Council in America.

[Mostowicz, Arnold] Rybak, Józef. 1954. Pamiętniki generała Rybaka. Warszawa: „Czytelnik" Spółdzielnia Wydawnicza.

Mroczka, Ludwik. 1990. Galicji rozstanie z Austrią. Zarys monograficzny. Kraków: Wydawnictwo Naukowe WSP.

Neck, Rudolf, wyd. 1968. Österreich im Jahre 1918. Berichte und Dokumente. Wien: Verlag für Geschichte und Politik.

Niebezpieczeństwo korytarza czesko-rosyjskiego. Konieczność granicy polsko-węgierskiej. Co mówi o tym prasa polska?. 1920. Warszawa: Drukarnia W. Piekarniaka.

„L'Occupation de la Galicie Orientale et de Lemkovchtchchina per les troupes polonaises”. 1921. Communiqué aux Membres de la Société des Nations, M 20/4/103/1, M 24/4/71/1.

Pankowicz, Andrzej. 1996. Analiza funkcjonowania miasta powiatowego. Studium Grybowa 1866-1932. Kraków: Wyższa Szkoła Biznesu - Księgarnia Akademicka.

(r). 1919. „Łemkowszczyzna”. Goniec Krakowski, 17.01.1919.

Regina-Zacharski, Jacek. 2004. Sprawa ukraińska w polityce Wielkiej Brytanii w latach 1917-1923. Toruń: Wydawnictwo Adam Marszałek.

Romer, Eugeniusz. 1989. Pamiętnik paryski 1918-1919. Wrocław: Zakład Narodowy im. Ossolińskich.

„Rusini”. 1918. Gazeta Podhalańska, 24.11.1918. 
Ruszała, Kamil. 2015. Wielka wojna w małym mieście. Gorlice w latach 1914-1918. Kraków: Towarzystwo Wydawnicze „Historia Iagellonica”.

Sierpowski, Stanisław. 1989. Źródła do historii powszechnej okresu międzywojennego, t. 1: 1917-1926. Poznań: Wydawnictwo Naukowe UAM.

Sladek, Zdenek, Valenta, Jaroslav. 1968. „Sprawy ukraińskie w czechosłowackiej polityce wschodniej w latach 1918-1922". W: Z dziejów stosunków polsko-radzieckich. Studia i materiały 3. Warszawa: Zakład Historii Stosunków Polsko-Radzieckich, Polska Akademia Nauk.

Text of the Treaty, Treaty of Peace Between The Allied and Associated Powers and Hungary And Protocol and Declaration, Signed at Trianon June 4, 1920. Dostęp: 20.12.2018. https://wwi.lib.byu.edu/index.php/Treaty_of_Trianon.

Volkonsky, Alexandre. 1920. The Ukrainian Question. The Historic Truth Versus the Separatist Propaganda. Rome.

Wilk, Stanisław, wyd. 2000. Acta Nuntiaturae Polonae, LVII, Achiles Ratti (1918-1921), cz. 6: 1 VIII 1919 - 31 X 1919. Romae: Fundatio Lanckoroński.

Zięba, Andrzej A. 1998. Ukraińcy w Kanadzie wobec Polaków i Polski, 1914-1939. Kraków: Księgarnia Akademicka.

Zięba, Andrzej A. 2010. „Polacy taktyczni a politycy nietaktowni: doświadczenie historyczne a świadomość polityczna elit władzy w Galicji w przededniu niepodległości”. W: Stan świadomości narodowej Polaków w przededniu niepodległości. Red. Jan Machnik, Wojciech Rojek, 57-70. Kraków: Polska Akademia Umiejętności.

Żurawski vel Grajewski, Przemysław Piotr. 1995. Sprawa ukraińska na konferencji pokojowej w Paryżu w roku 1919. Warszawa. Wydawnictwo Naukowe Semper.

Бочковський, І. Олгерд. 1930. Т. Г. Масарик. Національна проблема та українське питання. Подэбради.

Божик, Пантелеймон. 1927. Церков українців в Канаді. Вінніпег: Накладом «Канадийського Українця».

[Дуркот] Зынин, Сергей. 1934. Лемковына - Сьбыр. Львов.

Флюнт, Зіиовій. 1930. „Визвольний відгомин на Лемківщині”. Історичний календаральманах „Червоної Калини”, 5-9.

Гаттас, Наталия. 2016. „Онуфрий Гецев”. За руское дело, ч. 1: 6.

[Гладик, П. Виктор. 1917] В. П. Г-къ. Прикарпатская Русь (Галичина, Буковина и Угорская Русь). Winnipeg: Из типографіи «Русского Народа».

Гладик, П. Виктор. 1944. Проект меморандума американских граждан Карпаторусских и вообще русскаого происхожденя в деле восоединеня всех русских земель с Россиею. Филядельфя.

Когутов, Петро. b.d. Лемківщина в боротьбі за возз'еднання, mps.

„Колчак і сибірське українці”. 1919. Українські Роботнічі Вісті, 06.08.1919.

Коковський, Франц. 1935. „Лемківські републики з 1918-1919 роках”. Альманах «Червоної Калини», 115-118.

Копистянский, А. Скицко. 1919. „Всем уроженцам Прикарпатской Руси (Галицкой, Буковинской и Угорской Руси)”. Правительственый Вестник (Omsk), 08.06.1919. 
«Коротка история Лемко-Союза». 1979. 50th Anniversary Almanac of Lemko Association of USA \& Canada / Юбилейный альманах 50-літия Лемко-Союза в США и Канадi. New York: Yonkers.

Левицький, Кость. 1928. Історія визвольних змагань галицьких українців в часи світової війни 1914-1918 рр. Львів: Накладом власним.

Меморандумг Перваго Русскаго Конгресса въ Канадп состоявшагося въ Виннипегп на дняхъ 10, 11 и 12 н. с. іюня и в Мондеръ, Альта, 12 ілюля. [1917]. b.m.w.

Меморандумъ Народнаго Совета Русскаго Прикарпатя. 1918. Praha: E. Gregor.

„Народный съъздъ”. 1928. Лемко, ч. 1.

Ортоскоп. 1924. Державні змагання Прикарпатськой Украйни. Відень: Видаництво «Нова Громада».

Осечинський, Василь Костянтинович, Челак, Петро Петрович. 1957. „Вплив Жовтня на революційно-визвольну боротьбу у Західній Україні”. In: 40 років Великого Жовтня. Львів: Видавництво Львівського університету.

«Отъ редакции». 1928. Лемко, nr 1: 1.

Пиж, С. 1928. „Задачи Лемковского комитета”. Лемко, ч. 1.

Пельц, Степан. 1962. „Лемківська Республіка”. Вісті Братства кол. Вояків 1. УД УНА, ч. 107: 87.

Симоненко, Р.Г. 1957. „До питання про Східну Галиину напередодні Паризкої мирної конфереції". Наукові заиски Інституту історії Академії Наук УССР 9.

Шанковський, Лев. 1974. Украӥнська Галицька Армія. Воэнно-історична студія. Вінніпег: Димитро Микитюк.

Теодоровичъ, Иванъ. 1934. „Лемковская Русь”. Научно-літературний Сборник Гатицко-русской Матицы LXIX, nr 8.

Урядовий вистник (Omsk), 1919, nr 149, частина офицяльна, 01.06.1919.

Ваврик, Р. Василий. 1934. „Карпаторосы в Корниловском походе и Добровольчевской армии". Временник Ставропигяльного институту.

Ваврик, Р. Василий. b. d. „Русская Народная Республика Лемков”. mps.

Ваврик, Р. Василий. 1961. „Сергей Иванович Дуркот 1901-1944”. Карпаторусский календар Лемко-Союза, 67-74. https://essauty.livejournal.com/31155.html.

Войценко, Ольга. 1961. Літопис українського життя в Канаді. Вінніпег: Видавнича Спілка Тризуб.

„3 Лемківщини нам пишуть”. 1918. Діло, 10.1918. 